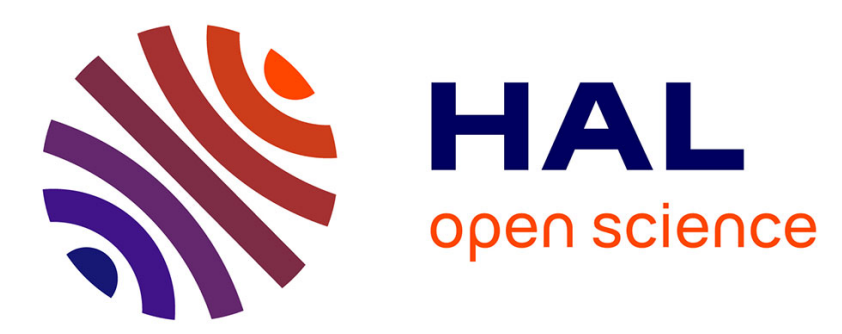

\title{
Comparison of the pharmacological properties of human and rat histamine H3-receptors
}

David Schnell, Andrea Strasser, Roland Seifert

\section{To cite this version:}

David Schnell, Andrea Strasser, Roland Seifert. Comparison of the pharmacological properties of human and rat histamine H3-receptors. Biochemical Pharmacology, 2010, 80 (9), pp.1437. 10.1016/j.bcp.2010.07.027 . hal-00623303

\section{HAL Id: hal-00623303 https://hal.science/hal-00623303}

Submitted on 14 Sep 2011

HAL is a multi-disciplinary open access archive for the deposit and dissemination of scientific research documents, whether they are published or not. The documents may come from teaching and research institutions in France or abroad, or from public or private research centers.
L'archive ouverte pluridisciplinaire HAL, est destinée au dépôt et à la diffusion de documents scientifiques de niveau recherche, publiés ou non, émanant des établissements d'enseignement et de recherche français ou étrangers, des laboratoires publics ou privés. 


\section{Accepted Manuscript}

Title: Comparison of the pharmacological properties of human and rat histamine $\mathrm{H} 3$-receptors

Authors: David Schnell, Andrea Strasser, Roland Seifert

PII: $\quad$ S0006-2952(10)00565-4

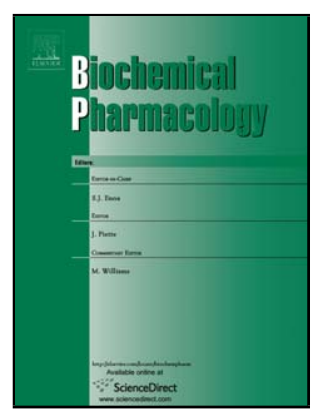

DOI: doi:10.1016/j.bcp.2010.07.027

Reference:

BCP 10660

To appear in: $\quad B C P$

Received date: $\quad 18-5-2010$

Revised date: $\quad 20-7-2010$

Accepted date: $\quad$ 23-7-2010

Please cite this article as: Schnell D, Strasser A, Seifert R, Comparison of the pharmacological properties of human and rat histamine H3-receptors, Biochemical Pharmacology (2010), doi:10.1016/j.bcp.2010.07.027

This is a PDF file of an unedited manuscript that has been accepted for publication. As a service to our customers we are providing this early version of the manuscript. The manuscript will undergo copyediting, typesetting, and review of the resulting proof before it is published in its final form. Please note that during the production process errors may be discovered which could affect the content, and all legal disclaimers that apply to the journal pertain. 


\title{
Comparison of the pharmacological properties of
}

\section{human and rat histamine $\mathrm{H}_{3}$-receptors}

\author{
David Schnell, Andrea Strasser and Roland Seifert \\ Department of Pharmacology and Toxicology, University of Regensburg, \\ D-93040 Regensburg, Germany (D. S.) \\ Department of Pharmaceutical/Medicinal Chemistry I, University of Regensburg, \\ D-93040 Regensburg, Germany (A. S.) \\ Institute of Pharmacology, Medical School of Hannover, \\ D-30625 Hannover, Germany (R. S.)
}

\section{Corresponding author:}

Dr. Roland Seifert, Institute for Pharmacology, Medical School of Hannover, Carl-NeubergStr. 1, D-30625 Hannover, Germany; Phone: +49-511-532-2805; Fax: +49-511-532-4081; email, seifert.roland@mh-hannover.de

Classification: Neuropharmacology

\begin{abstract}
Abbreviations used: GPCR, G protein-coupled receptor; GTP $\gamma$ S, guanosine 5'-[ $\gamma$ thio]triphosphate; h, human; $r$, rat; $\beta_{2} A R, \beta_{2}$-adrenoceptor; $H_{3} R$, histamine $H_{3}$-receptor, $H_{4} R$, histamine $\mathrm{H}_{4}$-receptor; TM, transmembrane domain; JNJ-7753707, (4-fluorophenyl)(1methyl-2-an-1 H-imidazol-5-yl)methanone; FUB181, 4-(3-(3-(4-chlorophenyl)propoxy)propyl)1 H-imidazole; A-304121, (R)-2-amino-1-(4-(3-(4-(cyclopropanecarbonyl)phenoxy)propyl)piperazin-1-yl)propan-1-one; fMLP, N-formyl-L-methionyl-L-leucyl-L-phenylalanine; THIO, thioperamide
\end{abstract}




\begin{abstract}
Ligand pharmacology of histamine $\mathrm{H}_{3}$-receptors is species-dependent. In previous studies, two amino acids in transmembrane domain 3 (TM III) were shown to play a significant role. In this study, we characterized human and rat histamine $\mathrm{H}_{3}$-receptors $\left(\mathrm{hH}_{3} \mathrm{R}\right.$ and $\mathrm{rH}_{3} \mathrm{R}$, respectively), co-expressed with mammalian G proteins in Sf9 insect cell membranes. We compared a series of imidazole-containing $\mathrm{H}_{3} \mathrm{R}$ ligands in radioligand binding and steadystate GTPase assays. $\mathrm{H}_{3}$ Rs similarly coupled to $\mathrm{G}_{\mathrm{i} / \mathrm{o}}$-proteins. Affinities and potencies of the agonists histamine, $N^{\alpha}$-methylhistamine and $R-(\alpha)$-methylhistamine were in the same range. Imetit was only a partial agonist. The pharmacology of imetit and proxifan was similar at both species. However, impentamine was more potent and efficacious at $\mathrm{rH}_{3} \mathrm{R}$. The inverse agonists ciproxifan and thioperamide showed higher potency but lower efficacy at $\mathrm{rH}_{3} \mathrm{R}$. Clobenpropit was not species-selective. Strikingly, imoproxifan was almost full agonist at $\mathrm{hH} \mathrm{H}_{3} \mathrm{R}$, but an inverse agonist at $\mathrm{rH}_{3} \mathrm{R}$. Imoproxifan was docked into the binding pocket of inactive and active $\mathrm{hH}_{3} \mathrm{R}$ - and $\mathrm{rH}_{3} \mathrm{R}$-models and molecular dynamic simulations were performed. Imoproxifan bound to $\mathrm{hH}_{3} \mathrm{R}$ and $\mathrm{rH}_{3} \mathrm{R}$ in $\mathrm{E}$-configuration, which represents the trans-isomer of the oxime-moiety as determined in crystallization studies, and stabilized active $\mathrm{hH}_{3} \mathrm{R}$-, but inactive $\mathrm{rH}_{3} \mathrm{R}$-conformations. Large differences in electrostatic surfaces between TM III and TM V cause differential orientation of the oxime-moiety of imoproxifan, which then differently interacts with the rotamer toggle switch $\operatorname{Trp}^{6.48}$ in TM VI. Collectively, the substantial species differences at $\mathrm{H}_{3} \mathrm{Rs}$ are explained at a molecular level by the use of novel $\mathrm{H}_{3} \mathrm{R}$ active-state models.
\end{abstract}

Key words: active receptor state; histamine $\mathrm{H}_{3}$-receptor; imoproxifan; molecular dynamics simulations; Sf9 insect cells 


\section{INTRODUCTION}

Histamine (HA) exhibits its biological effects through the activation of four different $G$ protein-coupled receptors (GPCRs). The histamine $H_{1}$-receptor $\left(H_{1} R\right)$ is associated with inflammatory and allergic reactions, e. g. it increases vascular permeability and NO production [1]. The histamine $\mathrm{H}_{2}$-receptor $\left(\mathrm{H}_{2} \mathrm{R}\right)$ regulates gastric acid production, but also shows a positive inotropic effect on the heart [1]. The histamine $H_{3}$-receptor $\left(H_{3} R\right)$ is a presynaptic auto- and heteroreceptor, regulating the release of $\mathrm{HA}$ and various other neurotransmitters in the nervous system, and is involved in important physiological processes like the sleep-wake cycle, eating behaviour and cognition [2]. The histamine $\mathrm{H}_{4^{-}}$ receptor $\left(\mathrm{H}_{4} \mathrm{R}\right)$ mediates inflammatory and immunological processes, e. g. chemotaxis of eosinophils, mast cells and dendritic cells, but it is also present on neurons mediating HAinduced itching $[3,4] . \mathrm{H}_{1} R$ and $\mathrm{H}_{2} \mathrm{R}$ antagonists have been used as therapeutics for decades, $\mathrm{H}_{3} \mathrm{R}$ and $\mathrm{H}_{4} \mathrm{R}$ are still explored and promising new drug targets [5].

The $\mathrm{H}_{3} \mathrm{R}$ was pharmacologically identified in the early 1980 s, but cloned almost 20 years later in 1999 as an orphan GPCR [2]. The reason for this delay was that it only shares $\sim 20 \%$ homology to the $\mathrm{H}_{1} R$ and $\mathrm{H}_{2} \mathrm{R}$. The complex gene structure of the human $\mathrm{H}_{3} R\left(\mathrm{hH}_{3} R\right)$ gives rise to many possible splice variants. To date about $20 \mathrm{hH}_{3} \mathrm{R}$ splice variants are known [6], but their function still remains elusive. The $\mathrm{H}_{3} \mathrm{R}$ displays high constitutive, i. e. ligandindependent, activity in many experimental systems [7]. The $\mathrm{H}_{3} \mathrm{R}$ is one of the very few GPCRs for which constitutive activity has also been demonstrated in vivo [8].

For the $\mathrm{H}_{3} \mathrm{R}$ it has also been shown that species-differences exist [9, 10]. Fig. 1 shows the amino acid sequences of $\mathrm{hH}_{3} \mathrm{R}$ and $\mathrm{rH}_{3} \mathrm{R}$. Although the $\mathrm{H}_{3} \mathrm{R}$ sequence has a high degree of similarity among species, differences located in key regions of the receptor protein account for differences in antagonist affinity [13,14]. Additionally, splice variants differ in composition and expression pattern between species, and there are potential differences in signal transduction processes between either tissues and/or species [15]. Nevertheless, there are still unresolved questions about species differences of the full-length and un- 
spliced $\mathrm{H}_{3} \mathrm{Rs}$ (445 amino acids), especially regarding the detailed molecular mechanisms

involved in ligand-receptor interactions.

In the present study, we systematically compared the pharmacological properties of $\mathrm{hH}_{3} \mathrm{R}$ and $\mathrm{rH}_{3} \mathrm{R}$. Fig. 2 shows the structures of the compounds studied, all of them being imidazole-containing ligands. We co-expressed $\mathrm{hH}_{3} \mathrm{R}$ and $\mathrm{rH}_{3} \mathrm{R}$ in $\mathrm{Sf9}$ cells together with mammalian $G$ proteins in a defined stoichiometry, determined the affinity of ligands in radioligand binding studies, and their potency and efficacy in steady-state GTPase assays. The baculovirus/Sf9 cell system is very suitable for the analysis of $G_{i} / G_{0}$-coupled receptors and in particular constitutively active receptors, because in $\mathrm{Sf} 9$ cells no endogenous $\mathrm{G}_{\mathrm{i}} / \mathrm{G}_{0^{-}}$ proteins or GPCRs with constitutive activity are present. The controlled expression of receptor and G proteins in Sf9 cell membranes represents more the physiological situation than, for example, the construction of GPCR-G $\alpha$ fusion proteins, because fusion proteins do not exist physiologically and the mobility of the G proteins is not restricted in the coexpression system. Moreover, the use of very proximal read-outs, like radioligand binding or steady-state GTPase assays prevent possible bias in later steps of the signal transduction cascade.

Many studies of ligand-receptor interactions come to a point where structural information on the atomic level is needed to explain experimental results. In the case of GPCRs, this is a very challenging and time-consuming process, and at the end only snapshots of static ligand-receptor complexes are resolved [16]. However, more and more high-resolution crystal structures of inactive- and active-state GPCR-ligand complexes are becoming available and can be used to generate better homology models $[17,18,19]$. Several molecular modelling studies with regard to ligand-receptor interaction at $\mathrm{H}_{3} \mathrm{R}$ are found in literature $[13,20,21,22]$. Since active-state models for $\mathrm{H}_{3} R$ s do not yet exist, we generated and used those models to explain the pharmacological species differences at $\mathrm{hH}_{3} \mathrm{R}$ and $\mathrm{rH}_{3} \mathrm{R}$ on the basis of experimental data. 


\section{MATERIALS AND METHODS}

\subsection{Materials.}

The $c$ DNAs of the $\mathrm{hH}_{3} \mathrm{R}$ and $\mathrm{rH}_{3} \mathrm{R}$ were kindly provided by Dr. T. Lovenberg (Johnson \& Johnson Pharmaceutical R\&D, San Diego, CA, USA). An alignment of the corresponding

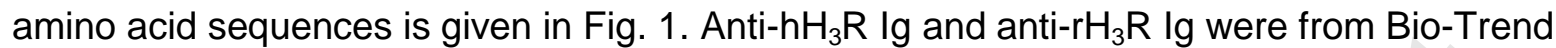
(Cologne, Germany). The antibody recognizing both species homologs was from GeneWay (San Diego, CA, USA). All other antibodies, purified G proteins, reagents for molecular biology, recombinant baculoviruses encoding mammalian G protein subunits, and the sources of test compounds were described before [23]. Chemical structures of $\mathrm{H}_{3} R$ ligands are depicted in Fig. 2. Stock solutions (10 mM) of all $\mathrm{H}_{3} \mathrm{R}$ ligands described in this paper were prepared in distilled water and stored at $-20^{\circ} \mathrm{C} .\left[{ }^{3} \mathrm{H}\right] \mathrm{JNJ}-7753707\left(=\left[{ }^{3} \mathrm{H}\right] \mathrm{RWJ}-422475\right)$ (30 Ci/mmol) was kindly donated from Dr. P. Bonaventure (Johnson \& Johnson Pharmaceutical R\&D, San Diego, CA, USA). $\left[{ }^{3} \mathrm{H}\right] N^{\alpha}$-methylhistamine $(74-85 \mathrm{Ci} / \mathrm{mmol})$ and $\left[{ }^{35} \mathrm{~S}\right] \mathrm{GTP} \gamma \mathrm{S}(1100 \mathrm{Ci} / \mathrm{mmol})$ were obtained from Perkin Elmer (Boston, MA, USA). $\left[\gamma^{-32} \mathrm{P}\right] \mathrm{GTP}$ was synthesized as described [23]. Unlabeled nucleotides were from Roche (Indianapolis, IN, USA) and all other reagents were of the highest purity available and from standard suppliers.

\subsection{Construction of FLAG epitope- and hexahistidine-tagged $c D N A s$ for $\mathrm{hH}_{3} \mathrm{R}$ and $\mathrm{rH}_{3} \mathrm{R}$.}

The cDNA for the tagged $\mathrm{rH}_{3} \mathrm{R}$ protein was generated by sequential overlap-extension PCR in analogy to the procedure described recently for $\mathrm{hH}_{3} \mathrm{R}$ [23]. In the case of $\mathrm{rH}_{3} \mathrm{R}$, the sense primer RAT HRH3-F- (5'- GAC GAT GAT GAC GCC ATG GAG CGC GCG CCG CC-3') consisted of $15 \mathrm{bp}$ of the 3'-end of SF and the first $17 \mathrm{bp}$ of the $5^{\text {'-end }}$-ef the $\mathrm{rH}_{3} \mathrm{R}$. The antisense primer RAT HRH3-RV (5'- GA TCC ICT AGA TTA GTG ATG GTG ATG ATG GTG CTT CCA GCA CTG CTC -3') consisted of 15 bp of the C-terminus of the $\mathrm{rH}_{3} \mathrm{R}$, and encoded a hexahistidine tag, the stop codon, and a $\underline{X b a I}$ site. As template, a plasmid ( $\mathrm{pClneo}$ ) containing the sequence of $\mathrm{rH}_{3} \mathrm{R}$ was used. 


\subsection{Generation of recombinant baculoviruses, cell culture and membrane preparation,}

\section{SDS-PAGE and immunoblot analysis.}

The protocols for virus amplification, protein expression and western blot analysis were described before [23]. Proteins transferred to nitrocellulose membranes were reacted with anti-hH $\mathrm{H}_{3} \mathrm{R}$ (N-term) (1:1000), anti-r $\mathrm{H}_{3} \mathrm{R}$ (C-term) (1:1000) and anti- $\mathrm{H}_{3} \mathrm{R}$ (i3) (1:1000) Igs.

\section{4. $\left[{ }^{35} \mathrm{~S}\right] \mathrm{GTP} \gamma \mathrm{S}$ saturation binding assay.}

Experiments were performed in analogy to the assay described in Schnell et al. [23].

Membranes were thawed and sedimented by a 10 -min centrifugation at $4^{\circ} \mathrm{C}$ and $15,000 \mathrm{~g}$ to remove residual endogenous guanine nucleotides as far as possible. Membranes were resuspended in binding buffer (12.5 $\mathrm{mM} \mathrm{MgCl}_{2}, 1 \mathrm{mM}$ EDTA, and $75 \mathrm{mM}$ Tris- $\mathrm{HCl}, \mathrm{pH}$ 7.4), supplemented with $0.05 \%(\mathrm{~m} / \mathrm{v})$ BSA. Each tube (total volume of 250 or $500 \mu \mathrm{l}$ ) contained 10 - $20 \mu \mathrm{g}$ of membrane protein. Tubes contained $0.2-2 \mathrm{nM}\left[{ }^{35} \mathrm{~S}\right] \mathrm{GTP} \gamma \mathrm{S}$ plus unlabeled GTP $\gamma \mathrm{S}$ to give the desired final ligand concentrations $(0.2-50 \mathrm{nM})$. Neither GDP nor $\mathrm{H}_{3} \mathrm{R}$ ligands were included in assays. Non-specific binding was determined in the presence of $100 \mu \mathrm{M}$ unlabeled GTP $\gamma$ S and amounted to less than $1 \%$ of total binding. Incubations were conducted for 90 minutes at $25^{\circ} \mathrm{C}$ and shaking at $250 \mathrm{rpm}$. Bound $\left[{ }^{35} \mathrm{~S}\right] \mathrm{GTP} \gamma \mathrm{S}$ was separated from free $\left[{ }^{35} \mathrm{~S}\right] \mathrm{GTP} \gamma \mathrm{S}$ by filtration through GF/C filters, followed by three washes with $2 \mathrm{ml}$ of binding buffer $\left(4^{\circ} \mathrm{C}\right)$. Filter-bound radioactivity was determined by liquid scintillation counting. The experimental conditions chosen ensured that not more than $10 \%$ of the total amount of radioactivity added to binding tubes was bound to filters. The maximum number of $\mathrm{G}_{\mathrm{i} / 0^{-}}$ related GTP $\gamma S$ binding sites in membranes expressing $H_{3} R$ s plus $G \alpha$-subunits plus $\beta_{1} \gamma_{2}$ was corrected by the binding determined in parallel in membranes expressing $\mathrm{H}_{3} \mathrm{Rs}$ plus $\beta_{1} \gamma_{2}$ alone. These reference membranes were always prepared under exactly the same conditions as the other ones. To ensure the same viral load in the reference membranes, Sf9 cells were infected with baculoviruses encoding $\mathrm{H}_{3} \mathrm{Rs}, \beta_{1} \gamma_{2}$ and virus encoding no recombinant protein at all. In this manner, only the number of functionally intact and heterologously expressed mammalian $\mathrm{G}_{\mathrm{i}_{\mathrm{i} /}}$-subunits was quantitated. 


\subsection{Steady-state GTPase activity assay.}

Experiments were performed in analogy to the assay described in Schnell et al. [23]. Briefly, membranes were thawed, sedimented and resuspended in $10 \mathrm{mM} \mathrm{Tris} / \mathrm{HCl}, \mathrm{pH}$ 7.4. Assay tubes contained Sf9 membranes (10 - $20 \mu \mathrm{g}$ of protein/tube), $5.0 \mathrm{mM} \mathrm{MgCl}, 0.1 \mathrm{mM}$ EDTA, $0.1 \mathrm{mM}$ ATP, $100 \mathrm{nM}$ GTP, $0.1 \mathrm{mM}$ adenylyl imidodiphosphate, $1.2 \mathrm{mM}$ creatine phosphate, $1 \mu \mathrm{g}$ of creatine kinase, and $0.2 \%(\mathrm{w} / \mathrm{v})$ bovine serum albumin in $50 \mathrm{mM} \mathrm{Tris} / \mathrm{HCl}, \mathrm{pH} 7.4$, and $\mathrm{H}_{3} \mathrm{R}$ ligands at various concentrations. Reaction mixtures $(80 \mu \mathrm{l})$ were incubated for 2 $\min$ at $25^{\circ} \mathrm{C}$ before the addition of $20 \mu \mathrm{l}$ of $\left[\gamma^{3}{ }^{32} \mathrm{P}\right] \mathrm{GTP}(0.1 \mu \mathrm{Ci} /$ tube $)$. All stock and work dilutions of $\left[\gamma^{-32} \mathrm{P}\right] \mathrm{GTP}$ were prepared in $20 \mathrm{mM}$ Tris $/ \mathrm{HCl}, \mathrm{pH}$ 7.4. Reactions were conducted for $20 \mathrm{~min}$ at $25^{\circ} \mathrm{C}$. Reactions were terminated by the addition of $900 \mu$ l of slurry consisting of $5 \%(\mathrm{w} / \mathrm{v})$ activated charcoal and $50 \mathrm{mM} \mathrm{NaH}_{2} \mathrm{PO}_{4}, \mathrm{pH}$ 2.0. Charcoal absorbs nucleotides but not $\mathrm{P}_{\mathrm{i}}$. Charcoal-quenched reaction mixtures were centrifuged for $7 \mathrm{~min}$ at room temperature at $15,000 \mathrm{~g}$. Six hundred microliters of the supernatant fluid of reaction mixtures were removed, and ${ }^{32} \mathrm{P}_{\mathrm{i}}$ was determined by liquid scintillation counting. Enzyme activities were corrected for spontaneous degradation of $\left[\gamma^{32} \mathrm{P}\right] \mathrm{GTP}$. Spontaneous $\left[\gamma^{32} \mathrm{P}\right] \mathrm{GTP}$ degradation was determined in tubes containing all of the above described components plus a very high concentration of unlabeled GTP $(1 \mathrm{mM})$ that, by competition with $\left[\gamma^{3{ }^{32}} \mathrm{P}\right] \mathrm{GTP}$, prevents $[\gamma-$ ${ }^{32}$ P]GTP hydrolysis by enzymatic activities present in Sf9 membranes. Spontaneous $[\gamma-$ ${ }^{32}$ P]GTP degradation was $<1 \%$ of the total amount of radioactivity added using $20 \mathrm{mM}$ Tris/ $\mathrm{HCl}, \mathrm{pH} 7.4$, as solvent for $\left[\gamma^{3}{ }^{32} \mathrm{P}\right] \mathrm{GTP}$. The experimental conditions chosen ensured that not more than $10 \%$ of the total amount of $\left[\gamma^{-32} \mathrm{P}\right] \mathrm{GTP}$ added was converted to ${ }^{32} \mathrm{P}$.

\subsection{Radioligand binding assays.}

Experiments were performed in analogy to the assay described in Schnell et al. [23]. Membranes were thawed and sedimented by a 10 -min centrifugation at $4^{\circ} \mathrm{C}$ and $15,000 \mathrm{~g}$ and resuspended in binding buffer $\left(12.5 \mathrm{mM} \mathrm{MgCl}_{2}, 1 \mathrm{mM}\right.$ EDTA, and $75 \mathrm{mM}$ Tris- $\mathrm{HCl}, \mathrm{pH}$ 7.4), to remove residual endogenous guanine nucleotides as much as possible. In $\left[{ }^{3} \mathrm{H}\right] \mathrm{NAMH}$ binding assays, each tube (total volume, 250 or $500 \mu \mathrm{l}$ ) contained 10 to $50 \mu \mathrm{g}$ of protein. 
Non-specific binding was determined in the presence of $\left[{ }^{3} \mathrm{H}\right] \mathrm{NAMH}$ at various concentrations plus $10 \mu \mathrm{M}$ THIO and amounted to $\sim 10 \%$ of total binding at saturating concentrations (10 $\mathrm{nM}$ ). Incubations were conducted for $60 \mathrm{~min}$ at RT and shaking at $250 \mathrm{rpm}$. Saturation binding experiments were carried out using 0.3 to $10 \mathrm{nM}\left[{ }^{3} \mathrm{H}\right] \mathrm{NAMH}$ in the presence or absence of $10 \mu \mathrm{M}$ GTP $\gamma$ S. In competition binding experiments, tubes contained $1 \mathrm{nM}$ $\left[{ }^{3} \mathrm{H}\right] \mathrm{NAMH}$ and unlabeled ligands at various concentrations. Bound $\left[{ }^{3} \mathrm{H}\right] \mathrm{NAMH}$ was separated from free $\left[{ }^{3} \mathrm{H}\right] \mathrm{NAMH}$ by filtration through GF/C filters pretreated with $0.3 \%(\mathrm{~m} / \mathrm{v})$ polyethyleneimine, followed by three washes with $2 \mathrm{ml}$ of binding buffer $\left(4^{\circ} \mathrm{C}\right) .\left[{ }^{3} \mathrm{H}\right] \mathrm{JNJ}$ $7753707\left(=\left[{ }^{3} \mathrm{H}\right] \mathrm{RWJ}-422475\right)$ binding experiments were performed using the same procedure as described above for $\left[{ }^{3} \mathrm{H}\right] \mathrm{NAMH}$. With $\left[{ }^{3} \mathrm{H}\right] \mathrm{JNJ}-7753707$ as radioligand, nonspecific binding was about $20-30 \%$ of total binding at saturating concentrations (10 nM). Filter-bound radioactivity was determined by liquid scintillation counting. The experimental conditions chosen ensured that not more than $10 \%$ of the total amount of radioactivity added to binding tubes was bound to filters.

\subsection{Construction of inactive and active models of $\mathrm{hH}_{3} \mathrm{R}$ and $\mathrm{rH}_{3} \mathrm{R}$.}

Based on the crystal structure of the human $\beta_{2}$-adrenergic receptor [17, 24], a homology model of the inactive $\mathrm{hH}_{3} \mathrm{R}$ and $\mathrm{rH}_{3} \mathrm{R}$ were generated. Based on the active state model of guinea pig $\mathrm{H}_{1} \mathrm{R}\left(\mathrm{gpH}_{1} \mathrm{R}\right)[25,26]$, an active model of $h \mathrm{H}_{3} \mathrm{R}$ was constructed by homology modelling. All models were refined and energetically minimized with SYBYL 7.0 (Tripos, St. Louis, MO, USA), as described [27]. Imoproxifan was docked manually into the binding pocket of the active $\mathrm{hH}_{3} \mathrm{R}$ and the inactive $\mathrm{rH}_{3} \mathrm{R}$. Thereby, previous results of similar compounds were taken into account $[20,21]$. The resulting structures were embedded in a simulation box, including lipid bilayer, water, sodium and chlorine ions, as described [28]. Subsequently, molecular dynamic simulations with GROMACS 3.3.1 [29] were performed, using a simulation protocol, previously described [28]. 


\subsection{Miscellaneous.}

Molecular biology was planned with GCK 2.5 (Textco BioSoftware, West Lebanon, NH, USA). Ligand structures were illustrated using ChemDraw Ultra 8.0 (CambridgeSoft, Cambridge, MA, USA). The sequence alignment was performed using ClustalX (2.0), which is a windows interface based on the Clustal W algorithm [30]. Protein was determined using the DC protein assay kit (Bio-Rad, Hercules, CA, USA). [ $\left.{ }^{3} \mathrm{H}\right]$ Dihydroalprenolol was obtained from Perkin Elmer (Boston, MA, USA) and protein quantification via western blot performed as described in Schnell et al. [23]. All analyses of experimental data were performed with the Prism 5 program (GraphPad Software, San Diego, CA, USA).

\section{RESULTS}

\subsection{Western blot analysis of $\mathrm{hH}_{3} \mathrm{R}$ and $\mathrm{rH}_{3} \mathrm{R}$ expressed in $\mathrm{Sf} 9$ insect cell membranes.}

Membranes of $\mathrm{Sf} 9$ cells expressing $\mathrm{hH}_{3} \mathrm{R}$ or $\mathrm{rH}_{3} \mathrm{R}$ plus mammalian $\mathrm{G}$ proteins were prepared and analyzed via immunoblot. It has to be mentioned, that membranes co-expressing $\mathrm{rH}_{3} \mathrm{R}$ plus different mammalian $G$ proteins were prepared in parallel and under exactly the same conditions as the membranes expressing $\mathrm{hH}_{3} \mathrm{R}$ [23]. Thus, the comparison of $h \mathrm{H}_{3} \mathrm{R}$ and $\mathrm{rH}_{3} \mathrm{R}$ pharmacology in this system is not based on historical data but direct. Both $\mathrm{hH}_{3} \mathrm{R}$ and $\mathrm{rH}_{3} \mathrm{R}$ bands were doublets, probably representing differently glycosylated forms (Fig. 3). $\mathrm{H}_{3} \mathrm{R}$ species homologs presumably exhibit similar glycosylation patterns since the putative $\mathrm{N}$ glycosylation site for the $\mathrm{H}_{3} \mathrm{R}$ (Asn11) is fully conserved within their sequences (Fig. 1). The $\mathrm{H}_{3} \mathrm{R}$ species homologs could be clearly discriminated by anti-hH $\mathrm{H}_{3} \mathrm{R}$ Ig, raised against an 18 amino acid peptide within the extracellular $\mathrm{N}$-terminus of the $\mathrm{hH}_{3} \mathrm{R}$, and anti-r $\mathrm{H}_{3} \mathrm{R} \lg$, raised against an 18 amino acid peptide within the cytoplasmatic C-terminus of the $\mathrm{rH}_{3} \mathrm{R}$ (Figs. 3A and $3 \mathrm{~B}$ ). Additionally, anti- $\mathrm{H}_{3} \mathrm{R}$ (i3) Ig was used to confirm the above mentioned results (Fig. 3C). This antibody was raised against a peptide sequence within the third intracellular loop (i3) of the $\mathrm{hH}_{3} \mathrm{R}$, but turned out to be not species-selective. Again, all $\mathrm{H}_{3} \mathrm{R}$ bands occurred as doublets at $\sim 49 \mathrm{kDa}$. However, there were some additional bands at lower molecular weight, which are presumably non-specific, since they also appeared at the control lane loaded with 
uninfected $\mathrm{Sf} 9$ cell membranes. Thus, our data indicate that $\mathrm{hH}_{3} \mathrm{R}$ and $\mathrm{rH}_{3} \mathrm{R}$ were equally well and properly expressed in Sf9 cells. In analogy to our recent publication [23], the $\mathrm{rH}_{3} \mathrm{R}$ was also co-expressed with different mammalian $G$ proteins $\left(G \alpha_{i 1}, G \alpha_{i 2}, G \alpha_{i 3}\right.$ or $G \alpha_{01}$, and $\beta_{1} \gamma_{2}$ dimers, respectively) to analyze the coupling profile. All proteins were properly detected by different selective antibodies (Fig. 3). Moreover, we also quantified the expression levels of receptors and $G$ proteins by immunoblot, using $h \beta_{2} A R$ or purified $G$ protein subunits as standards (Fig. 3D and 3H, I). The results of these studies are summarized in Table 1.

\subsection{Quantitative analysis of receptor-to-G protein stoichiometries.}

Protein quantification via western blot is semi-quantitative and does not discriminate between functional and non-functional proteins. Therefore, we directly used a recently described combination of antagonist $\left[{ }^{3} \mathrm{H}\right] \mathrm{JNJ}-7753707-$ and $\left[{ }^{35} \mathrm{~S}\right] \mathrm{GTP} \gamma \mathrm{S}$-saturation binding [23] and calculated the functional GPCR/G $\alpha$ protein ratios (Table 1). Similar to the membranes expressing $h H_{3} R$, we detected an excess of mammalian $G$ proteins in the case of $\mathrm{rH}_{3} R$, confirming the previously reported results [23]. Thus, G protein expression level is not limiting in this experimental system, too.

\section{3. $\mathrm{hH}_{3} \mathrm{R}$ and $\mathrm{rH}_{3} \mathrm{R}$ coupling to different $\mathrm{G} \alpha$-subunits.}

The $G$ protein coupling profile of $\mathrm{rH}_{3} \mathrm{R}$ (Table 2) was also investigated as for the $\mathrm{hH}_{3} \mathrm{R}$ [23]. Briefly, receptor-dependent $\left[\gamma_{-}{ }^{32} \mathrm{P}\right] \mathrm{GTP}$ hydrolysis of different $\mathrm{G} \alpha$-subunits was measured under steady-state conditions. GTPase activities were determined in parallel under basal conditions, maximal stimulation with the physiological (and full) agonist histamine (10 $\mu \mathrm{M})$ and a saturating concentration of the inverse agonist thioperamide $(10 \mu \mathrm{M})$ in Sf9 cell membranes co-expressing the $\mathrm{rH}_{3} \mathrm{R}$ and different $\mathrm{G}$ proteins.

Like $\mathrm{hH}_{3} \mathrm{R}, \mathrm{rH}_{3} \mathrm{R}$ coupled efficiently to all co-expressed mammalian $\mathrm{G \alpha}_{\mathrm{i} / 0}$-subunits $\left(G \alpha_{i 1}, G \alpha_{i 2}, G \alpha_{i 3}\right.$ or $G \alpha_{01}$, and $\beta_{1} \gamma_{2}$ dimers, respectively), as was evident by the high basal GTPase activities and the large absolute stimulatory and inhibitory effects of histamine and thioperamide, respectively (Table 2). Also, the relative stimulatory effects of histamine and 
the relative inhibitory effects of thioperamide based on total ligand-regulated GTPase activity were similar for each of the four systems studied, indicating that the constitutive activity of $\mathrm{rH}_{3} \mathrm{R}$ was comparable and not substantially influenced by the type of $\mathrm{G}$ protein (Table 2). The constitutive activity of $\mathrm{rH}_{3} R$ coupled to cognate $\mathrm{G}_{\mathrm{i}} / \mathrm{G}_{\mathrm{o}}$-proteins was rather high and comparable to the constitutive activity of $\mathrm{hH}_{3} \mathrm{R}$, rendering the two systems suitable for an analysis of species-specific ligand effects, without possible bias due to differences in basal activity between membranes.

\subsection{Ligand potencies and efficacies in the steady-state GTPase assay at $\mathrm{rH}_{3} \mathrm{R}$ compared to $\mathrm{hH}_{3} \mathrm{R}$ co-expressed with different $\mathrm{G} \alpha$-subunits.}

Next, we examined a series of imidazole-based ligands in Sf9 cell membranes expressing

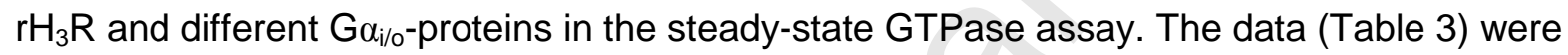
then compared with the results for $\mathrm{hH}_{3} \mathrm{R}$ [23] (Fig. $4 \mathrm{~A}$ and $\mathrm{B}$ ). The endogenous agonist histamine (1) and the standard $\mathrm{H}_{3} \mathrm{R}$ ligands $N^{\alpha}$-methylhistamine (2) and $(R)-\alpha-$ methylhistamine (3) were full agonists and equally potent in all membranes. There were essentially no species-differences. The highly potent standard $\mathrm{H}_{3} \mathrm{R}$ agonist imetit (4) was almost a full agonist at $\mathrm{rH}_{3} \mathrm{R}$, too. Interestingly, proxifan (5) was again a strong partial agonist in all systems, independent of the $\mathrm{G}$ protein subtype co-expressed, corroborating the notion that this ligand does not show functional selectivity at $\mathrm{H}_{3} \mathrm{Rs}$ [23]. In contrast to $\mathrm{hH}_{3} R$, impentamine (6) was a strong and more potent partial agonist at $\mathrm{rH}_{3} \mathrm{R}$ in all experimental settings. Strikingly, imoproxifan (7) was an almost full agonist at $\mathrm{hH}_{3} \mathrm{R}$ (Fig. 5A), but an inverse agonist at $\mathrm{rH}_{3} \mathrm{R}$ (Fig. 5B). The type of $\mathrm{G}$ protein subunit did not change the pharmacological profile of imoproxifan (Table 3). The inverse agonists ciproxifan (8) and thioperamide (10) were more potent but less efficacious at $\mathrm{rH}_{3} \mathrm{R}$ than at $\mathrm{hH}_{3} \mathrm{R}$ and again, the G protein subtype caused no changes in their profiles. Clobenpropit (9) was neither speciesspecific nor did the G protein subtype change its pharmacology. Moreover, there is also a strong linear correlation between potencies and efficacies of imidazole-based ligands at

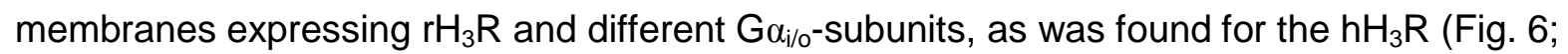


Table 3). Thus, the pharmacological profile of the $\mathrm{rH}_{3} \mathrm{R}$ is also very similar under the various experimental conditions and, like at $\mathrm{hH}_{3} \mathrm{R}$, ligand-specific receptor conformations leading to coupling differences do not exist for the compounds investigated [23].

Collectively, these results confirm the findings regarding the relative stimulatory and inhibitory effects of histamine and thioperamide, respectively (Table 2), based on total ligandregulated GTPase activity and are indicative for similar constitutive activity of $\mathrm{hH}_{3} \mathrm{R}$ and $\mathrm{rH}_{3} \mathrm{R}$ under all experimental conditions. If there had been differences in constitutive activity between $\mathrm{hH}_{3} \mathrm{R}$ and $\mathrm{rH}_{3} \mathrm{R}$, then systematic changes in the potencies of full agonists as well as potencies and efficacies of partial agonists and inverse agonists would have occurred. This, however, was not the case. In contrast, the behaviour of ligands, e. g. impentamine or imoproxifan, at one $\mathrm{H}_{3} \mathrm{R}$ species homolog often opposed each other, against every expectation. Thus, these ligand effects are solely species-specific and not due to differences in constitutive activity of $\mathrm{hH}_{3} \mathrm{R}$ and $\mathrm{rH}_{3} \mathrm{R}$.

\section{5. $\left[{ }^{3} \mathrm{H}\right]$ NAMH binding studies at $\mathrm{hH}_{3} \mathrm{R}$ and $\mathrm{rH}_{3} \mathrm{R}$.}

Since the type of G protein co-expressed did not change the pharmacology of ligands at both $\mathrm{hH}_{3} \mathrm{R}$ and $\mathrm{rH}_{3} \mathrm{R}$ in the steady-state GTPase assay, we performed radioligand binding experiments for a further characterization only at membranes expressing $\mathrm{hH}_{3} \mathrm{R}$ or $\mathrm{rH}_{3} \mathrm{R}$ plus G $\alpha_{\mathrm{i} 2}$ plus $\beta_{1} \gamma_{2}$ dimers.

At first, we addressed the formation of a high-affinity ternary complex between the agonist $\left[{ }^{3} \mathrm{H}\right] \mathrm{NAMH}$, the $\mathrm{hH}_{3} \mathrm{R}$ or $\mathrm{rH}_{3} \mathrm{R}$ and nucleotide-free $\mathrm{G}$ protein in saturation binding experiments (Fig. $5 \mathrm{C}$ and D). The $K_{\mathrm{d}}$ of $\left[{ }^{3} \mathrm{H}\right] \mathrm{NAMH}$ at $\mathrm{hH}_{3} \mathrm{R}$ was $0.62 \pm 0.21 \mathrm{nM}$, and the $B_{\max }$ was $0.62 \pm 0.02 \mathrm{pmol} / \mathrm{mg}(\mathrm{n}=3)$. At $\mathrm{rH}_{3} \mathrm{R}$, the $K_{\mathrm{d}}$ value was $1.37 \pm 0.36 \mathrm{nM}$, and the $B_{\max }$ was $0.48 \pm 0.03 \mathrm{pmol} / \mathrm{mg}(\mathrm{n}=3)$. Interestingly, binding of $\left[{ }^{3} \mathrm{H}\right] \mathrm{NAMH}$ was only slightly GTP $\gamma$ S-sensitive in both cases. The $K_{d}$ values of $\left[{ }^{3} \mathrm{H}\right] \mathrm{NAMH}$ in the presence of GTP $\gamma \mathrm{S}$ (10 $\mu \mathrm{M}$ ) were about 2-fold lower, but the $B_{\max }$ values did not change significantly (Fig. $5 \mathrm{C}$ and D). 
In competition binding experiments (Fig. 4 C), histamine (1) (Fig. $5 \mathrm{E}$ and F), $N^{\alpha}{ }_{-}$ methylhistamine (2), (R)- $\alpha$-methylhistamine (3), imetit (4) and proxifan (5) had essentially the same affinities at $\mathrm{hH}_{3} \mathrm{R}$ and $\mathrm{rH}_{3} \mathrm{R}$. Impentamine (6), imoproxifan (7) (Fig. $5 \mathrm{E}$ and F), ciproxifan (8) and thioperamide (10) (Fig. $5 \mathrm{E}$ and F) bound with higher affinity to $\mathrm{rH}_{3} \mathrm{R}$. Clobenpropit (9) also bound with similar affinity to both receptors. The pharmacological profiles, determined in $\left[{ }^{3} \mathrm{H}\right] \mathrm{NAMH}$ competition binding (Table 4) and steady-state GTPase assays (Table 3), compared with the literature, were very similar [31, 32]. The $\mathrm{p} K_{\mathrm{i}}$ and $\mathrm{p} E C_{50}$ values determined at $\mathrm{hH}_{3} \mathrm{R}$ correlated well, suggesting a direct signal transfer in the Sf9 cell system (Fig. 7). However, at $\mathrm{rH}_{3} \mathrm{R}$, the correlation coefficient was rather low, due to an extraordinary high affinity of impentamine (6). Interestingly, the $\mathrm{p} K_{\mathrm{i}}$ values of imoproxifan (7) were significantly lower than the corresponding $\mathrm{p} E C_{50}$ values determined in the GTPase assay $(t$ test, $p<0.05)$.

\subsection{Binding mode of imoproxifan at $\mathrm{hH}_{3} \mathrm{R}$ and $\mathrm{rH}_{3} \mathrm{R}$.}

To understand the molecular basis for the unique behaviour of imoproxifan, we performed molecular modelling studies with $\mathrm{hH}_{3} \mathrm{R}$ and $\mathrm{rH}_{3} \mathrm{R}$. The binding modes of imoproxifan at active $\mathrm{hH}_{3} \mathrm{R}$ and inactive $\mathrm{rH}_{3} \mathrm{R}$, representing the most favoured ligand-receptor-complexes, are presented in Fig. 8.

Imoproxifan is bound to $\mathrm{hH}_{3} \mathrm{R}$ and $\mathrm{rH}_{3} \mathrm{R}$ in $E$-configuration, representing the transisomer of the oxime-moiety. The E-configuration was also determined to be the favoured one by crystallographic studies [33]. The electrostatic surface potential of the amino acids with the ligand in the binding pocket is shown (Fig. 8, A and B). In $\mathrm{hH}_{3} \mathrm{R}$ and $\mathrm{rH}_{3} \mathrm{R}$, the positively charged terminal imidazole moiety of imoproxifan interacts with the highly conserved Asp ${ }^{3.32}$ (Fig. 8, A and B, black arrow). However, there are large differences in electrostatic surface between TM V and TM III (Fig. 8, A and B, yellow, dotted line). In this region, the electrostatic surface potential is positive in $\mathrm{hH}_{3} \mathrm{R}$ due to the $\mathrm{NH}$ moiety of $\operatorname{Trp}^{6.48}$, The analoguous region in $\mathrm{rH}_{3} \mathrm{R}$ shows a slightly negative potential due to the $\mathrm{OH}$ moiety of $\mathrm{Thr}^{6.52}$. The consequence is a different orientation, and thus a different hydrogen bond networking of the oxime moiety 
of imoproxifan. In $\mathrm{hH}_{3} \mathrm{R}$, the methyl moiety points into direction of $T M V$, whereas in $\mathrm{rH}_{3} \mathrm{R}$, the methyl moiety points downward.

The reason for the differences in electrostatic surface potential between $\mathrm{hH}_{3} \mathrm{R}$ and $\mathrm{rH}_{3} \mathrm{R}$ are explained by the amino acid difference at position 3.37 between $\mathrm{hH}_{3} \mathrm{R}$ and $\mathrm{rH}_{3} \mathrm{R}$. In $\mathrm{hH}_{3} \mathrm{R}$, Glu ${ }^{5.46}$ can electrostatically interact with $\mathrm{Thr}^{3.37}$ (Fig. 8, C, yellow, dotted line). Thus, Glu ${ }^{5.46}$ points towards $\mathrm{Thr}^{3.37}$ and away from the binding pocket. Consequently, the electrostatic potential surface in this region is neutral and a small pocket for the methyl moiety of imoproxifan is build. In contrast, in $\mathrm{rH}_{3} \mathrm{R}, \mathrm{Thr}^{3.37}$ is exchanged into $\mathrm{Ala}^{3.37}$. Thus, an electrostatic interaction between Glu ${ }^{5.46}$ and the amino acid side chain in position 3.37 is no longer possible. Instead, the modelling studies revealed an electrostatic interaction of Glu ${ }^{5.46}$ and $\mathrm{Tyr}^{3.33}$ in $\mathrm{rH}_{3} \mathrm{R}$ (Fig. 8, D, yellow, dotted line). Consequently, the negatively charged side chain of Glu ${ }^{5.46}$ points partially toward the binding pocket, resulting in an aromatic contact between $\mathrm{Tyr}^{3.33}$ and the imoproxifan.

A second species-difference between $\mathrm{hH}_{3} \mathrm{R}$ and $\mathrm{rH}_{3} \mathrm{R}$ near to the binding pocket is located at position 3.40. There is an alanine in $\mathrm{hH}_{3} \mathrm{R}$, but a bulkier valine in $\mathrm{rH}_{3} \mathrm{R}$ (Fig. 8, C and $\mathrm{D}$, green, dotted line). It is likely that this amino acid difference also directs the oxime moiety of imoproxifan into a distinct orientation. Since $\mathrm{Ala}^{3.40}$ is not as bulky as $\mathrm{Val}^{3.40}$, there is more space for the oxime moiety to point downward in direction to 3.40 in $\mathrm{hH}_{3} \mathrm{R}$, than in $\mathrm{rH}_{3} \mathrm{R}$.

Additionally, $\operatorname{Tr}^{6.48}$ is shown in its active conformation at $\mathrm{hH}_{3} \mathrm{R}$ (Fig. 8, C, blue arrow) and in its inactive conformation in $\mathrm{rH}_{3} \mathrm{R}$ (Fig. 8, D, blue arrow). $\operatorname{Trp}^{6.48}$ is part of a highly conserved motif among GPCRs, thought to function as a toggle-switch during receptor activation, as is evident due to structural and biophysical studies [34]. Trp ${ }^{6.48}$ horizontal to the membrane surface stabilizes the active state of a GPCR. Trp ${ }^{6.48}$ vertical to the membrane surface stabilizes the inactive state of a GPCR. As consequence of the different amino acids at position 3.37 and 3.40 between $\mathrm{hH}_{3} \mathrm{R}$ and $\mathrm{rH}_{3} \mathrm{R}$, the oxime moiety of imoproxifan can establish a hydrogen bond interaction to $\operatorname{Tr}^{6.48}$ in its active conformation, thus stabilizing the active conformation of $\mathrm{hH}_{3} \mathrm{R}$ (Fig. 8, E, yellow, dotted line). This interaction was not found in 
$\mathrm{rH}_{3} \mathrm{R}$. Here, the hydrogen of the oxime moiety interacts electrostatically with a negatively charged surface established by $\mathrm{Thr}^{6.52}$ (Fig. 8, F, yellow, dotted line). In $\mathrm{rH}_{3} \mathrm{R}$, the methyl group of imoproxifan is located in a small pocket established by Val ${ }^{3.40}$ and $\operatorname{Trp}^{6.48}$ in its inactive conformation.

Collectively, the different binding modes of imoproxifan in $\mathrm{hH}_{3} \mathrm{R}$ and $\mathrm{rH}_{3} \mathrm{R}$ presumably lead to differences in efficacies due to a different orientation of the oxime moiety and thus, stabilization of $\operatorname{Trp}^{6.48}$ either horizontal or vertical to the membrane surface.

In contrast to imoproxifan (7), ciproxifan (8) (Fig. 4B) was found to act as an inverse agonist at $h H_{3} \mathrm{R}$ as well as at $r \mathrm{H}_{3} \mathrm{R}$. This observation is quite interesting, since both compounds only differ in the substitution pattern at the phenyl moiety (Fig. 2). To obtain more insight into these pharmacological differences, we docked ciproxifan (8) into the binding pocket of the active conformation of $\mathrm{hH}_{3} \mathrm{R}$ and performed a minimization with regard to potential energy. An overlay with the corresponding imoproxifan $-\mathrm{hH}_{3} \mathrm{R}-$ complex showed, that the cyclopropyl moiety of ciproxifan (8), which is more space-filling than the methyl moiety of imoproxifan (7), lead to a shift of the neighbouring Glu ${ }^{5.46}$ away from the binding pocket. Subsequently, the hydrogen bond between $\mathrm{Glu}^{5.46}$ and $\mathrm{Thr}^{3.37}$ is broken, which may lead to a destabilization of the entire ligand-receptor complex. In contrast, ciproxifan (8) could be docked very well into the binding pocket of the inactive $\mathrm{hH}_{3} \mathrm{R}$. The resulting binding mode is similar to that of imoproxifan (7) at the inactive $\mathrm{rH}_{3} \mathrm{R}$. Since there is the smaller alanine in position 3.40 at $\mathrm{hH}_{3} \mathrm{R}$ (compared to valine at $\mathrm{rH}_{3} \mathrm{R}$ ), the more space-filling cycloproyl moiety fits optimally into this small pocket at $\mathrm{hH}_{3} \mathrm{R}$. However, the exchange of the oxime moiety into a carbonyl moiety in ciproxifan (8) leads to the loss of one hydrogen bond between ligand and receptor, as found for imoproxifan (Fig. 8F).

\section{DISCUSSION}

Ligand pharmacology at $\mathrm{hH}_{3} \mathrm{R}$ and $\mathrm{rH}_{3} \mathrm{R}$ is species-dependent (Fig. 4) [35, 36]. Unexpectedly, the species-differences can even span from agonism to inverse agonism in the case of imoproxifan [36]. In this study, we unraveled the underlying molecular 
mechanism of this reversal in efficacy. In steady-state GTPase assays, imoproxifan was an

inverse agonist at $\mathrm{rH}_{3} \mathrm{R}$, but almost full agonist at $\mathrm{hH}_{3} \mathrm{R}$. Competition binding studies with $\left[{ }^{3} \mathrm{H}\right] \mathrm{NAMH}$ confirmed that the effect was receptor-mediated. Both $\mathrm{hH}_{3} \mathrm{R}$ and $\mathrm{rH}_{3} \mathrm{R}$ were expressed at similar levels and defined receptor-to-G protein stoichiometries. The basal activity in the two systems was comparable, as indicated by the similar inhibitory effects of the standard inverse agonist thioperamide. Thus, the unexpected behaviour of imoproxifan can only be due to species-specific differences in ligand recognition and receptor activation. Previous modelling studies described the binding mode of FUB181, a compound, similar to imoproxifan [21]. The orientation of imoproxifan in the binding pocket of $\mathrm{H}_{3} \mathrm{R}$, determined in the present study, is similar to these previous findings. In another study, it was suggested, that the $\mathrm{Ala}^{3.40} \mathrm{Val}$ amino acid difference between $\mathrm{hH}_{3} \mathrm{R}$ and $\mathrm{rH}_{3} \mathrm{R}$ is responsible for the observed species-differences in antagonist pharmacology [13]. It was pointed out that thioperamide or compound $\mathrm{A}-304121$ are in closer contact to $\mathrm{Val}^{3.40}$ in $\mathrm{rH}_{3} \mathrm{R}$, than to $\mathrm{Ala}^{3.40}$ in $\mathrm{hH}_{3} \mathrm{R}$. We could reproduce this finding because the affinity and potency of thioperamide was higher at $\mathrm{rH}_{3} \mathrm{R}$ than $\mathrm{hH}_{3} \mathrm{R}$ in our experimental system, too. Our molecular modelling studies further revealed that both amino acid differences in TM III, at position 3.37 and 3.40, are responsible for the differences in pharmacology of imoproxifan between $\mathrm{hH}_{3} \mathrm{R}$ and $\mathrm{rH}_{3} \mathrm{R}$. The oxime moiety points downward in direction of $\mathrm{Ala}^{3.40}$ in $\mathrm{hH}_{3} \mathrm{R}$. Thus, the polar oxime moiety is able to establish a hydrogen bond interaction with $\operatorname{Tr}^{6.48}$ in its active conformation. In contrast, in $\mathrm{rH}_{3} \mathrm{R}$, the oxime moiety points toward TM V. Additionally, the methyl moiety of imoproxifan fits optimally into a small pocket between the bulky Val ${ }^{3.40}$ and $\operatorname{Trp}^{6.48}$ in its inactive conformation. The highly conserved $\operatorname{Trp}^{6.48}$ is suggested to act as a switch for receptor activation within biogenic amine receptors. $\operatorname{Tr}^{6.48}$ oriented horizontally to the membrane surface is thought to stabilize the active state of a receptor, while $\operatorname{Trp}^{6.48}$ oriented vertically to the membrane surface stabilizes the inactive state of a receptor. Since the hydrogen bond interaction between the oxime moiety and $\operatorname{Trp}^{6.48}$ stabilizes $\operatorname{Trp}^{6.48}$ in its active conformation in $\mathrm{hH}_{3} \mathrm{R}$, the partial agonism of imoproxifan is explained on a molecular level. This hydrogen bond-supported stabilization of $\operatorname{Trp}^{6.48}$ in its active conformation is not possible 
in $\mathrm{rH}_{3} \mathrm{R}$. Here, in contrast to $\mathrm{hH}_{3} \mathrm{R}$, the methyl group near $\mathrm{Val}^{3.40}$ and $\operatorname{Trp}^{6.48}$ stabilizes $\operatorname{Trp}^{6.48}$ in its inactive conformation due to a hydrophobic interaction. Thus, the modelling studies provide an explanation for the inverse agonism of imoproxifan at $\mathrm{rH}_{3} \mathrm{R}$ on a molecular level, too. Additionally, the molecular modelling studies could be used to explain the switch from partial agonism of imoproxifan (7) to inverse agonism of ciproxifan (8) at $\mathrm{hH}_{3} \mathrm{R}$. The modelling studies suggest that the main reason for this is the more space-filling cycloproyl moiety of ciproxifan (8), compared to the methyl moiety in imoproxifan (7). This leads to a loss of hydrogen bonding between $\mathrm{Glu}^{5.46}$ and $\mathrm{Thr}^{3.37}$. Furthermore, a hydrogen bond between the carbonyl moiety and the $\mathrm{NH}$ moiety of $\operatorname{Trp}^{6.48}$, stabilizing the active conformation of $\mathrm{hH}_{3} \mathrm{R}$, could not be established.

Interestingly, the $\mathrm{p} K_{\mathrm{i}}$ values imoproxifan (7) at $\mathrm{hH}_{3} \mathrm{R}$ and $\mathrm{rH}_{3} \mathrm{R}$ were significantly higher than their $\mathrm{p} E C_{50}$ values ( $t$ test, $p<0.05$ ). These results suggest that $\mathrm{hH}_{3} \mathrm{R}$ and $\mathrm{rH}_{3} \mathrm{R}$ can exist in a state of low partial agonist/inverse agonist affinity that interacts efficiently with G proteins. Another study, analyzing the $\mathrm{hH}_{3} \mathrm{R}$ expressed in SK-N-MC cells by $\left.{ }^{3} \mathrm{H}\right] \mathrm{NAMH}$ competition binding and CRE- $\beta$-galactosidase reporter gene assays, revealed similar disparities [31]. Similar results were also obtained when the human formyl peptide receptor, coupled to various $G_{i}$-proteins, was studied in Sf9 cell membranes [37]. In this study, the $K_{d}$ of the agonist radioligand $\left[{ }^{3} \mathrm{H}\right] \mathrm{fMLP}$ was $\sim 100$-fold lower than the $E C_{50}$ determined in GTPase experiments. Interestingly, at $\mathrm{hH}_{3} \mathrm{R}$ expressed in $\mathrm{Sf} 9$ cells the low affinity state stabilized by imoproxifan (7) leads to an activation of $\mathrm{G}$ proteins, whereas in $\mathrm{rH}_{3} \mathrm{R}$, the low affinity state inhibited the activation of $G$ proteins.

The $\mathrm{G}$ protein coupling profile of $\mathrm{hH}_{3} \mathrm{R}$ and $\mathrm{rH}_{3} \mathrm{R}$ was similar, too (Table 2; in [23]). An important fact is that like for $\mathrm{hH}_{3} \mathrm{R}$ [23], at $\mathrm{rH}_{3} \mathrm{R}$ no evidence for functional selectivity was observed (Table 3). However, in another study, evidence for functional selectivity at $\mathrm{H}_{3} R$ could be obtained [38]. Possible reasons for those discrepancies were already previously discussed [23]. Both $\mathrm{hH}_{3} \mathrm{R}$ and $\mathrm{rH}_{3} \mathrm{R}$ coupled effectively with $\mathrm{G}_{i} / \mathrm{G}_{\mathrm{o}}$-proteins in Sf9 cell membranes, as was shown by GTP $\gamma$ S-insensitive ternary complex formation, using $\left[{ }^{3} \mathrm{H}\right] \mathrm{NAMH}$ as radioligand, and steady-state $\left[\gamma^{-32} \mathrm{P}\right] \mathrm{GTP}$ hydrolysis. The similarly small shifts 
of the $\left[{ }^{3} \mathrm{H}\right] \mathrm{NAMH}$ saturation binding curves at $\mathrm{hH}_{3} \mathrm{R}$ and $\mathrm{rH}_{3} \mathrm{R}$ by GTP $\gamma \mathrm{S}$ indicate a similarly strong interaction of both receptors with the $G$ protein and are in line with the high constitutive activity of the $\mathrm{H}_{3}$ Rs. Thus, the results confirm the data of the GTPase experiments. In line with the data for $\mathrm{hH}_{3} \mathrm{R}$ and $\mathrm{rH}_{3} \mathrm{R}$, high-affinity agonist binding to the structurally closely related histamine $\mathrm{H}_{4}$-receptor is also largely GTP $\gamma \mathrm{S}$-insensitive [39]. The $\mathrm{H}_{4}$-receptor possesses very high constitutive activity as well. Similar constitutive activity renders the system well suited for the analysis of species-specific ligand effects, since differences in constitutive activity between GPCRs can alter their pharmacological profiles and lead to a further complication of data interpretation [40, 41].

The pharmacology of all histamine receptors $\left(H_{x} R s\right)$ is species-dependent. This is especially true for $\mathrm{H}_{x} R$ agonists. At the $\mathrm{H}_{1} R$, several classes of bulky ligands exhibit species differences [42]. Some of them show unique behaviours, like epimeric members of the ergoline family or chiral histaprodifens, switching from silent antagonism to partial agonism depending on the species studied [28,43]. Detailed molecular studies dissected some of the underlying mechanisms $[26,44]$. At the $\mathrm{H}_{2} \mathrm{R}$, bulky agonists like the long-chained impromidine- and arpromidine-derived guanidines or $N^{\natural}$-acylated imidazolylpropylguanidines (AIPGs), are more potent and efficacious at the $\mathrm{gpH}_{2} \mathrm{R}$ than at the $\mathrm{hH}_{2} \mathrm{R}[37,45]$. Metiamide was identified to be an inverse agonist at the $\mathrm{hH}_{2} \mathrm{R}, \mathrm{gpH}_{2} \mathrm{R}$ and $\mathrm{rH}_{2} \mathrm{R}$, but a weak partial agonist at the $\mathrm{cH}_{2} \mathrm{R}$ [40]. At the $\mathrm{H}_{4} \mathrm{R}$, which has the lowest sequence similarity between species, studies focusing on ligand-receptor interactions of agonists are beginning to emerge $[27,46]$. However, the species-differences of imoproxifan at $\mathrm{hH}_{3} \mathrm{R}$ and $\mathrm{rH}_{3} \mathrm{R}$ described in this study represent the most substantial differences in pharmacology among $\mathrm{H}_{\mathrm{x}} \mathrm{Rs}$ identified so far. This is particularly compelling in view of the fact that $h \mathrm{H}_{3} \mathrm{R}$ and $\mathrm{rH}_{3} \mathrm{R}$ sequences display a high degree of homology and only two amino acid residues cause the disparities.

In conclusion, we have shown that $\mathrm{hH}_{3} \mathrm{R}$ and $\mathrm{rH}_{3} \mathrm{R}$ expressed in $\mathrm{Sf9}$ cells both similarly couple to defined $G_{i} / G_{0}$-protein heterotrimers and display similar constitutive activities. We show species-differences in pharmacological properties of imoproxifan and offer an explanation on the molecular basis for these differences. Most importantly, we 
introduce novel active state models of $\mathrm{hH}_{3} \mathrm{R}$ and $\mathrm{rH}_{3} \mathrm{R}$, that are suitable to explain the efficacy of $\mathrm{H}_{3} \mathrm{R}$ ligands.

\section{ACKNOWLEDGEMENTS}

We would like to thank Mrs. G. Wilberg and Mrs. A. Seefeld for their excellent technical assistance. Thanks are also due to the reviewers for their helpful suggestions. This work was supported by the Research Training Program (Graduiertenkolleg) [GRK760] "Medicinal Chemistry: Molecular Recognition - Ligand-Receptor Interactions" of the German Research Foundation (DFG). The authors are affiliated with COST Action [BM0806]. 


\section{REFERENCES}

[1] Hill SJ, Ganellin CR, Timmerman H, Schwartz JC, Shankley NP, Young JM, et al. International Union of Pharmacology. XIII. Classification of histamine receptors. Pharmacol Rev 1997;49:253-78.

[2] Leurs R, Bakker RA, Timmerman $\mathrm{H}$, de Esch IJ (2005) The histamine $\mathrm{H}_{3}$ receptor: from gene cloning to $\mathrm{H}_{3}$ receptor drugs. Nat Rev Drug Discov 2005;4:107-20.

[3] Leurs R, Chazot PL, Shenton FC, Lim HD, de Esch IJ. Molecular and biochemical pharmacology of the histamine $\mathrm{H}_{4}$ receptor. $\mathrm{Br} \mathrm{J}$ Pharmacol 2009;157:14-23.

[4] Zampeli E, Tiligada E. The role of histamine $\mathrm{H}_{4}$ receptor in immune and inflammatory disorders. Br J Pharmacol 2009;157:24-33.

[5] Tiligada E, Zampeli E, Sander K, Stark $\mathrm{H}$. Histamine $\mathrm{H}_{3}$ and $\mathrm{H}_{4}$ receptors as novel drug targets. Expert Opin Investig Drugs 2009;18:1519-31.

[6] Bongers G, Bakker RA, Leurs R. Molecular aspects of the histamine $\mathrm{H}_{3}$ receptor. Biochem Pharmacol 2007;73:1195-204.

[7] Arrang JM, Morisset S, Gbahou F. Constitutive activity of the histamine $\mathrm{H}_{3}$ receptor. Trends Pharmacol Sci 2007;28:350-57.

[8] Morisset S, Rouleau A, Ligneau X, Gbahou F, Tardivel-Lacombe J, Stark H, et al. High constitutive activity of native $\mathrm{H}_{3}$ receptors regulates histamine neurons in brain. Nature 2000;408:860-64.

[9] Ireland-Denny L, Parihar AS, Miller TR, Kang CH, Krueger KM, Esbenshade TA, et al. Species-related pharmacological heterogeneity of histamine $\mathrm{H}_{3}$ receptors. Eur $\mathrm{J}$ Pharmacol 2001;433:141-50.

[10] Wulff BS, Hastrup S, Rimvall K. Characteristics of recombinantly expressed rat and human histamine $\mathrm{H}_{3}$ receptors. Eur J Pharmacol 2002;453:33-41.

[11] Ballesteros $\mathrm{JH}$, Weinstein $\mathrm{H}$. Integrated methods for the construction of three dimensional models and computational probing of structure-funtion relations in G-protein coupled receptors. Methods Neurosci 1995;25:366-428. 
[12] Uveges AJ, Kowal D, Zhang J, Spangler TB, Dunlop J, Semus S, et al. The role of transmembrane helix 5 in agonist binding to the human histamine $\mathrm{H}_{3}$ receptor. $\mathrm{J}$ Pharmacol Exp Ther 2002;301:451-58.

[13] Yao BB, Hutchins CW, Carr TL, Cassar S, Masters JN, Bennani YL, et al. Molecular modeling and pharmacological analysis of species-related histamine $\mathrm{H}_{3}$ receptor heterogeneity. Neuropharmacology 2003;44:773-86.

[14] Ligneau X, Morisset S, Tardivel-Lacombe J, Gbahou F, Ganellin CR, Stark H, et al. Distinct pharmacology of rat and human histamine $\mathrm{H}_{3}$ receptors: role of two amino acids in the third transmembrane domain. Br J Pharmacol 2000;131:1247-50.

[15] Hancock AA, Esbenshade TA, Krueger KM, Yao BB. Genetic and pharmacological aspects of histamine $\mathrm{H}_{3}$ receptor heterogeneity. Life Sci 2003;73:3043-72.

[16] Kobilka B, Schertler GF. New G-protein-coupled receptor crystal structures: insights and limitations. Trends Pharmacol Sci 2008;29:79-83.

[17] Rasmussen SG, Choi HJ, Rosenbaum DM, Kobilka TS, Thian FS, Edwards PC, et al. Crystal structure of the human $\beta_{2}$-adrenergic G-protein-coupled receptor. Nature 2007;450:383-87.

[18] Jaakola VP, Griffith MT, Hanson MA, Cherezov V, Chien EY, Lane JR, et al. The $2.6 \AA$ crystal structure of a human $A_{2 A}$ adenosine receptor bound to an antagonist. Science 2008;322:1211-17.

[19] Park JH, Scheerer P, Hofmann KP, Choe HW,Ernst OP. Crystal structure of the ligandfree G-protein-coupled receptor opsin. Nature 2008;454:183-87.

[20] Stark H, Sippl W, Ligneau X, Arrang JM, Ganellin CR, Schwartz JC, et al. Different antagonist binding properties of human and rat histamine $\mathrm{H}_{3}$ receptors. Bioorg Med Chem Lett 2001;11:951-54.

[21] Schlegel B, Laggner C, Meier R, Langer T, Schnell D, Seifert R, et al. Generation of a homology model of the human histamine $\mathrm{H}_{3}$-receptor for ligand docking and pharmacophore-based screening. J Comput Aided Mol Des 2007;21:437-53. 
[22] Rai BK, Tawa GJ, Katz AH, Humblet C. Modeling G protein-coupled receptors for structure-based drug discovery using low-frequency normal modes for refinement of homology models: Application to $\mathrm{H}_{3}$ antagonists. Proteins 2010;78:457-73.

[23] Schnell D, Burleigh K, Trick J, Seifert R. No evidence for functional selectivity of proxifan at the human histamine $\mathrm{H}_{3}$-receptor coupled to defined $\mathrm{G}_{\mathrm{i}} / \mathrm{G}_{0}$ protein heterotrimers. J Pharmacol Exp Ther 2010;332:996-1005.

[24] Cherezov V, Rosenbaum DM, Hanson MA, Rasmussen SG, Thian FS, Kobilka TS, et al. High-resolution crystal structure of an engineered human $\beta_{2}$-adrenergic $G$ proteincoupled receptor. Science 2007;318:1258-65.

[25] Strasser A, Wittmann HJ. Analysis of the activation mechanism of the guinea-pig Histamine $\mathrm{H}_{1}$-receptor. J Comput Aided Mol Des 2007;21:499-509.

[26] Strasser A, Wittmann HJ, Seifert R. Ligand-specific contribution of the $\mathrm{N}$ terminus and E2-loop to pharmacological properties of the histamine $\mathrm{H}_{1}$-receptor. J Pharmacol Exp Ther 2008;326:783-91.

[27] Igel P, Geyer R, Strasser A, Dove S, Seifert R, Buschauer A. Synthesis and structureactivity relationships of cyanoguanidine-type and structurally related histamine $\mathrm{H}_{4}$ receptor agonists. J Med Chem 2009;52:6297-6313.

[28] Strasser A, Striegl B, Wittmann HJ, Seifert R. Pharmacological profile of histaprodifens at four recombinant histamine $\mathrm{H}_{1}$-receptor species isoforms. J Pharmacol Exp Ther 2008;324:60-71.

[29] van der Spoel D, Lindahl E, Hess B, Groenhof G, Mark AE, Berendsen HJC. GROMACS: fast, flexible, and free. J Comput Chem 2005;26:1701-18.

[30] Thompson JD, Higgins DG, Gibson TJ. CLUSTAL W: improving the sensitivity of progressive multiple sequence alignment through sequence weighting, position-specific gap penalties and weight matrix choice. Nucleic Acids Res 1994;22:4673-80

[31] Lim HD, van Rijn RM, Ling P, Bakker RA, Thurmond RL, Leurs R. Evaluation of histamine $\mathrm{H}_{1^{-}}, \mathrm{H}_{2^{-}}$, and $\mathrm{H}_{3}$-receptor ligands at the human histamine $\mathrm{H}_{4}$ receptor: 
identification of 4-methylhistamine as the first potent and selective $\mathrm{H}_{4}$ receptor agonist. $\mathrm{J}$ Pharmacol Exp Ther 2005;314:1310-21.

[32] Bongers G, Krueger KM, Miller TR, Baranowski JL, Estvander BR, Witte DG, et al. An 80-amino acid deletion in the third intracellular loop of a naturally occurring human histamine $\mathrm{H}_{3}$ isoform confers pharmacological differences and constitutive activity. $\mathrm{J}$ Pharmacol Exp Ther 2007;323:888-98.

[33] Sasse A, Sadek B, Ligneau X, Elz S, Pertz HH, Luger P, et al. New histamine $\mathrm{H}_{3^{-}}$ receptor ligands of the proxifan series: imoproxifan and other selective antagonists with high oral in vivo potency. J Med Chem 2000;43:3335-43.

[34] Ahuja S and Smith SO. Multiple switches in G protein-coupled receptor activation. Trends Pharmacol Sci 2009;30:494-502.

[35] Lovenberg TW, Pyati J, Chang H, Wilson SJ, Erlander MG. Cloning of rat histamine $\mathrm{H}_{3}$ receptor reveals distinct species pharmacological profiles. J Pharmacol Exp Ther 2000;293:771-778.

[36] Esbenshade TA, Estvander BR, Miller TR, Baranowski JL, Sharma R, Hancock AA, Krueger KM. Pharmacological classification of histamine $\mathrm{H}_{3}$ receptor agents across species is attributable to transmembrane 3 sequence differences. Inflamm Res 2007;56 Suppl 1:S45-S46.

[37] Wenzel-Seifert K, Arthur JM, Liu HY, Seifert R. Quantitative analysis of formyl peptide receptor coupling to $\mathrm{G}_{\alpha_{1} 1}, \mathrm{G}_{\alpha_{\mathrm{i} 2}}$, and $\mathrm{G}_{\alpha_{\mathrm{i} 3}}$. J Biol Chem 1999;274:33259-66.

[38] Krueger KM, Witte DG, Ireland-Denny L, Miller TR, Baranowski JL, Buckner S, Milicic I, Esbenshade TA, Hancock AA. G protein-dependent pharmacology of histamine $\mathrm{H}_{3}$ receptor ligands: evidence for heterogeneous active state receptor conformations. J Pharmacol Exp Ther 2005;314:271-278.

[39] Schneider EH, Schnell D, Papa D, Seifert R. High constitutive activity and a G-proteinindependent high-affinity state of the human histamine $\mathrm{H}_{4}$-receptor. Biochemistry 2009;48:1424-1438. 
[40] Preuss H, Ghorai P, Kraus A, Dove S, Buschauer A, Seifert R. Constitutive activity and ligand selectivity of human, guinea pig, rat, and canine histamine $\mathrm{H}_{2}$ receptors. $\mathrm{J}$ Pharmacol Exp Ther 2007;321:983-95.

[41] Preuss H, Ghorai P, Kraus A, Dove S, Buschauer A, Seifert R. Mutations of Cys-17 and Ala-271 in the human histamine $\mathrm{H}_{2}$ receptor determine the species selectivity of guanidine-type agonists and increase constitutive activity. J Pharmacol Exp Ther 2007;321:975-82.

[42] Seifert R, Wenzel-Seifert K, Bürckstümmer T, Pertz HH, Schunack W, Dove S, et al. Multiple differences in agonist and antagonist pharmacology between human and guinea pig histamine $\mathrm{H}_{1}$-receptor. J Pharmacol Exp Ther 2003;305:1104-15.

[43] Pertz HH, Gornemann T, Schurad B, Seifert R, Strasser A. Striking differences of action of lisuride stereoisomers at histamine $\mathrm{H}_{1}$ receptors. Naunyn Schmiedebergs Arch Pharmacol 2006;374:215-22.

[44] Strasser A, Wittmann HJ, Kunze M, Elz S, Seifert R. Molecular basis for the selective interaction of synthetic agonists with the human histamine $\mathrm{H}_{1}$-receptor compared with the guinea pig $\mathrm{H}_{1}$-receptor. Mol Pharmacol 2009;75:454-465.

[45] Kelley MT, Bürckstümmer T, Wenzel-Seifert K, Dove S, Buschauer A, Seifert R. Distinct interaction of human and guinea pig histamine $\mathrm{H}_{2}$-receptor with guanidine-type agonists. Mol Pharmacol 2001;60:1210-1225.

[46] Lim HD, Jongejan A, Bakker RA, Haaksma E, de Esch IJ, Leurs R. Phenylalanine 169 in the second extracellular loop of the human histamine $\mathrm{H}_{4}$ receptor is responsible for the difference in agonist binding between human and mouse $\mathrm{H}_{4}$ receptors. J Pharmacol Exp Ther 2008;327:88-96. 


\section{FIGURE CAPTIONS}

Fig. 1. Comparison of the amino acid sequences of $\mathrm{hH}_{3} \mathrm{R}$ (GeneBank Accession No. AF140538) and $\mathrm{rH}_{3} \mathrm{R}$ (GeneBank Accession No. AF237919). Putative transmembrane domains are stated above the sequences and indicated by a solid line. $\mathrm{N}$-term, extracellular $\mathrm{N}$-terminal domain of $\mathrm{H}_{3} \mathrm{Rs}$; C-term, intracellular C-terminal domain of $\mathrm{H}_{3} \mathrm{Rs} ; \mathrm{i}$, i2, and i3, first, second, and third intracellular loops; e1, e2, e3, first, second, and third extracellular loops, respectively. Dots in the sequence of $\mathrm{rH}_{3} \mathrm{R}$ indicate identity with $\mathrm{hH}_{3} \mathrm{R}$. Amino acids shown in regular fonts in the sequence of $\mathrm{rH}_{3} \mathrm{R}$ represent conservative differences, those shown in bold represent non-conservative differences. The most conserved residues in each TM domain are indicated in grey shading. Residues within TM domains are named according to the Ballesteros/Weinstein nomenclature. The most conserved residue in each TM is numbered as $X .50$, where $X$ is the number of the respective TM domain [11]. Amino acids shown in white with black shading represent a putative glycosylation site of the $\mathrm{H}_{3} \mathrm{R}$. Amino acids in frame represent putative interaction sites of $\mathrm{HA}$ with the $\mathrm{H}_{3} R[12,13]$.

Fig. 2. Structures of imidazole-containing $\mathrm{H}_{3} \mathrm{R}$-ligands: full agonists 1-3, partial agonists 4-6, imoproxifan 7, and antagonists/inverse agonists 8-10.

Fig. 3. Immunological detection of $\mathrm{hH}_{3} \mathrm{R}$ and $\mathrm{rH}_{3} \mathrm{R}$ expressed in $\mathrm{Sf9}$ cells. Each lane of the gels was loaded with $10 \mu \mathrm{g}$ of membrane protein, unless otherwise indicated below the film. Numbers on the left designate masses of marker proteins in $\mathrm{kDa}$. In $\mathbf{A}$ and $\mathbf{B}$, membranes expressing the $\mathrm{hH}_{3} \mathrm{R}$ and $\mathrm{rH}_{3} \mathrm{R}$ alone were loaded onto the gels. Proteins

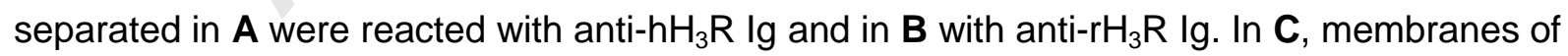
A and $\mathbf{B}$ plus control were analyzed. Here, the proteins were reacted with the non-speciesselective anti-hH ${ }_{3} \mathrm{R}$ (i3) Ig. In D1 and D2, 2, 4, 6, 8 and $10 \mu \mathrm{g}$ of protein of Sf9 membranes expressing $h \beta_{2} A R$ at $7.5 \mathrm{pmol} / \mathrm{mg}$ (as determined by $\left[{ }^{3} \mathrm{H}\right]$ dihydroalprenolol saturation binding) were used as standard to assess the expression levels of the $\mathrm{rH}_{3} \mathrm{R}$ in different membrane preparations with anti-FLAG Ig. In E, the same membranes were reacted with anti-His6 Ig. In 
$\mathbf{F}$, the membranes were reacted with anti-G $\alpha_{i-c o m m o n} \lg . \ln \mathbf{G}$, the membranes were reacted with anti-G $\mathrm{G}_{\beta \text {-common }} \lg$. In $\mathbf{H}, 0.5,1.0,1.5$ and $2.0 \mu \mathrm{g}$ of a membrane expressing the $\mathrm{rH}_{3} \mathrm{R}+$ $G \alpha_{i 2}+\beta_{1} \gamma_{2}$ was analyzed in order to quantify the $G \alpha$-subunits, using $2,4,7.5,15$ and $30 \mathrm{pmol}$ of purified $\mathrm{G}_{\mathrm{i} 2}$ as standard. In I, 0.5, 1.0, 1.5 and $2.0 \mu \mathrm{g}$ of a corresponding membrane of the same batch expressing $\mathrm{rH}_{3} R+G \alpha_{01}+\beta_{1} \gamma_{2}$ was analyzed to quantify the $G \alpha$-subunits, using 2, 4, 7.5, 15 and 30 pmol of purified $G \alpha_{02}$ an almost identical splice variant of $G \alpha_{01}$ as standard.

Fig. 4. Comparison of the pharmacological properties of $\mathrm{hH}_{3} \mathrm{R}$ and $\mathrm{rH}_{3} \mathrm{R}$. A, Comparison of the potencies of ligands in the GTPase assay. Data for $\mathrm{hH}_{3} \mathrm{R}$ were taken from Ref. 23, data for $\mathrm{rH}_{3} \mathrm{R}$ were taken from Table 3. B, Comparison of the efficacies of ligands in the GTPase assay. Data for $\mathrm{hH}_{3} \mathrm{R}$ were taken from Ref. 23, data for $\mathrm{rH}_{3} \mathrm{R}$ were taken from Table 3. C, Comparison of the affinities of ligands in the $\left[{ }^{3} \mathrm{H}\right] \mathrm{NAMH}$ competition binding assay. Data were taken from Table 4.

\section{Fig. 5. Comparison of the effects of histamine, imoproxifan and thioperamide in} membranes co-expressing the $\mathrm{hH}_{3} \mathrm{R}$ or $\mathrm{rH}_{3} \mathrm{R}, \mathrm{Ga}_{\mathrm{i} 2}$ subunits and $\beta_{1} \gamma_{2}$ dimers. $\mathrm{A}$ and $\mathrm{B}$, Steady-state GTPase activity in Sf9 membranes was determined as described under Methods. Reaction mixtures contained HA, IMO or THIO at the concentrations indicated on the abscissa to achieve saturation. Data are expressed as percentage change in GTPase activity induced by the ligands compared to the GTPase activity stimulated by HA (10 $\mu \mathrm{M})$, which was defined to be $100 \%$. Data were analyzed by nonlinear regression and were best fit to sigmoidal concentration/response curves. Data points shown are the means $\pm S$. E. M. of 3 - 4 independent experiments performed in duplicate. A summary of all results is shown in Table 3. $\mathbf{C}$ and $\mathbf{D},\left[{ }^{3} \mathrm{H}\right] \mathrm{NAMH}$ saturation binding experiments were performed as described under Methods. Data were analyzed by nonlinear regression and were best fitted to hyperbolic one-site saturation isotherms. The closed circles $(\bullet)$ show the data for the specific $\left[{ }^{3} \mathrm{H}\right] \mathrm{NAMH}$ binding in the absence of GTP $\gamma \mathrm{S}(10 \mu \mathrm{M})$, the open circles $(0)$ in the presence of GTP $\gamma \mathbf{S}(10 \mu \mathrm{M})$. In $\mathbf{C}, \mathrm{hH}_{3} \mathrm{R}$ was analyzed and in $\mathbf{D}, \mathrm{rH}_{3} \mathrm{R}$ was analyzed. Data points shown 
are the means $\pm \mathrm{S}$. E. M. of 3 independent experiments performed in triplicate, using three different membrane preparations. $\mathbf{E}$ and $\mathbf{F},\left[{ }^{3} \mathrm{H}\right] \mathrm{NAMH}$ binding was determined as described under Methods. Reaction mixtures contained Sf9 membranes (10 - $50 \mu \mathrm{g}$ of protein per tube) expressing the recombinant proteins, $1 \mathrm{nM}\left[{ }^{3} \mathrm{H}\right] \mathrm{NAMH}$, and ligands at the concentrations indicated on the abscissa. $\mathbf{E}$, competition binding at $\mathrm{hH}_{3} \mathrm{R}$ and $\mathbf{F}$, competition binding at $\mathrm{rH}_{3} \mathrm{R}$. Data were analyzed for best fit to monophasic competition curves ( $F$ test). Data points shown are the means $\pm \mathrm{S}$. E. M. of 3 - 5 independent experiments performed in duplicate.

Fig. 6. Correlation of potency and efficacy of ligands at the $\mathrm{rH}_{3} \mathrm{R}$ in the presence of different co-expressed $\mathrm{G}_{\boldsymbol{a}_{\mathrm{i} / \mathrm{o}}}$-proteins. Data shown in Table 3 were analyzed by linear regression. Numbers designate individual ligands decoded in Fig. 2. In A, C and E, the potencies of ligands at membranes co-expressing the $\mathrm{rH}_{3} \mathrm{R}, \mathrm{G} \alpha_{\mathrm{i1}}, \mathrm{G} \alpha_{\mathrm{i} 3}$ or $\mathrm{G} \alpha_{01}$, and $\beta_{1} \gamma_{2^{-}}$ dimers, respectively, were correlated with values determined at the reference membrane expressing $\mathrm{G}_{\mathrm{i} 2}$. A, $r^{2}=0.77 ;$ slope $=0.99 \pm 0.19$. C, $r^{2}=0.97 ;$ slope $=1.17 \pm 0.07$. E, $r^{2}=$ 0.96; slope $=1.05 \pm 0.07$. In $\mathbf{B}, \mathbf{D}$ and $\mathbf{F}$, the efficacies of ligands at membranes coexpressing the $\mathrm{rH}_{3} \mathrm{R}, \mathrm{G} \alpha_{\mathrm{i1}}, \mathrm{G} \alpha_{\mathrm{i} 3}$ or $\mathrm{G} \alpha_{01}$, and $\beta_{1} \gamma_{2}$ dimers, respectively, were correlated with values determined at the reference membrane expressing $\mathrm{G}_{\alpha_{2} 2} . \mathbf{B}, r^{2}=0.99$; slope $=0.97 \pm$ 0.04. D, $r^{2}=0.96$; slope $=0.99 \pm 0.07 . \mathbf{F}, r^{2}=0.996$; slope $=1.20 \pm 0.03$. The dotted lines indicate the $95 \%$ confidence intervals of the regression lines. The diagonal dashed line has a slope of 1 and represents a theoretical curve for identical values.

Fig. 7. Correlation of affinity and potency of ligands at the $\mathrm{hH}_{3} \mathrm{R}$ and $\mathrm{rH}_{3} \mathrm{R}$. Data shown were analyzed by linear regression. Numbers designate individual ligands decoded in Fig. 2 . In $\mathbf{A}$, the affinities and potencies of ligands at membranes co-expressing the $\mathrm{hH}_{3} \mathrm{R}, \mathrm{G}_{\mathrm{i} 2}$ and $\beta_{1} \gamma_{2}$ dimers were correlated. $\mathbf{A}, r^{2}=0.83$; slope $=0.94 \pm 0.15$. In $\mathbf{B}$, the affinities and potencies of ligands at membranes co-expressing the $\mathrm{rH}_{3} \mathrm{R}, \mathrm{G} \alpha_{\mathrm{i} 2}$ and $\beta_{1} \gamma_{2}$ dimers were correlated. B, $r^{2}=0.50$; slope $=0.83 \pm 0.29$. The dotted lines indicate the $95 \%$ confidence 
intervals of the regression lines. The diagonal dashed line has a slope of 1 and represents a theoretical curve for identical values.

\section{Fig. 8. Binding mode of imoproxifan at the active $\mathrm{hH}_{3} \mathrm{R}$ and inactive $\mathrm{rH}_{3} \mathrm{R}$.}

A, electrostatic potential surface in the binding pocket of active $\mathrm{hH}_{3} \mathrm{R}$ with imoproxifan in its binding conformation. B, electrostatic potential surface in the binding pocket of the inactive $\mathrm{rH}_{3} \mathrm{R}$ with imoproxifan in its binding conformation. $\mathbf{A}$ and $\mathbf{B}$, yellow dotted circle: the electrostatic potential is rather positive at $\mathrm{hH}_{3} \mathrm{R}$ due to the $\mathrm{NH}$ moiety of $\operatorname{Trp}^{6.48}$, but slightly negatively charged in $\mathrm{rH}_{3} \mathrm{R}$ due to the $\mathrm{OH}$ moiety of $\mathrm{Thr}^{6.52}$. The consequence is a different orientation of the ligands oxime moiety. $\mathbf{C}$, conformation of amino acids in the imoproxifan bound state of active $\mathrm{hH}_{3} \mathrm{R}$. $\mathbf{D}$, conformation of amino acids in the imoproxifan bound state of inactive $\mathrm{rH}_{3} \mathrm{R}$. $\mathbf{C}$ and $\mathbf{D}$, yellow dotted circle: important differences in side chain conformation of $\mathrm{Glu}^{5.46}$ between $\mathrm{hH}_{3} \mathrm{R}$ and $\mathrm{rH}_{3} \mathrm{R}$. At $\mathrm{hH}_{3} \mathrm{R}$, Glu $\mathrm{u}^{5.46}$ interacts with $\mathrm{Thr}^{3.37}$ and points away from the binding pocket. In $\mathrm{rH}_{3} \mathrm{R}, \mathrm{Thr}^{3.37}$ is exchanged to $\mathrm{Ala}^{3.37}$. Thus, the interaction between Glu $^{5.46}$ and the amino acid in position 3.37 is no longer possible and Glu $^{5.46}$ interacts with $\mathrm{Tyr}^{3.33}$. Green dotted circle: in position 3.40 , there is a small Ala in $\mathrm{hH}_{3} \mathrm{R}$, but the more bulky Val at $\mathrm{rH}_{3} \mathrm{R}$. It is suggested that this species difference is also be important for the different orientations of the oxime moiety between $\mathrm{hH}_{3} \mathrm{R}$ and $\mathrm{rH}_{3} \mathrm{R}$. $\mathbf{E}$, interaction between imoproxifan and $\mathrm{hH}_{3} R$; $\mathbf{F}$, interaction between imoproxifan and $\mathrm{rH}_{3} \mathrm{R}$. $\mathbf{E}$ and $\mathbf{F}$, yellow dotted circle: at $\mathrm{hH}_{3} \mathrm{R}$, the oxime moiety of imoproxifan points downwards and stabilizes the highly conserved $\operatorname{Trp}^{6.48}$ in its active conformation by a hydrogen bond; at $\mathrm{rH}_{3} \mathrm{R}$, the oxime moiety of imoproxifan points upwards to TM V and interacts with $\mathrm{Thr}^{6.52}$. 


\section{TABLES}

Table 1: Quantification of $\mathrm{rH}_{3} \mathrm{R}$-to-G protein ratios via western blot, $\left[{ }^{3} \mathrm{H}\right] \mathrm{JNJ}-7753707-$ and $\left[{ }^{35} \mathrm{~S}\right] \mathrm{GTP} \gamma \mathrm{S}$-saturation binding.

\begin{tabular}{|c|c|c|c|c|}
\hline \multirow{3}{*}{ membrane } & \multicolumn{4}{|c|}{$B_{\max } \pm$ S. E. M. $\left(p m o l \times \mathrm{mg}^{-1}\right)$} \\
\hline & \multicolumn{4}{|c|}{$\mathrm{rH}_{3} \mathrm{R}+\beta_{1} \gamma_{2}$} \\
\hline & $+G \alpha_{i 1}$ & $+\mathrm{Ga}_{\mathrm{i} 2}$ & $+\mathrm{Ga}_{\alpha_{3}}$ & $+G \alpha_{01}$ \\
\hline $\begin{array}{l}\text { immunoblot: } \\
\text { anti-FLAG Ig }\end{array}$ & $\sim 1.5-2.5$ & $\sim 1.5-2.5$ & $\sim 1.5-2.5$ & $\sim 1.5-2.5$ \\
\hline anti-G $\alpha$ lgs & n. d. & $\sim 50-100$ & n. d. & $\sim 50-100$ \\
\hline$\left[{ }^{3} \mathrm{H}\right] \mathrm{JNJ}-7753707$ & $0.67 \pm 0.03$ & $0.77 \pm 0.02$ & $1.05 \pm 0.04$ & $1.25 \pm 0.04$ \\
\hline$\left[{ }^{35} \mathrm{~S}\right] \mathrm{GTP} \gamma \mathrm{S}$ & $3.40 \pm 0.80$ & $4.43 \pm 0.53$ & $2.52 \pm 0.37$ & $8.19 \pm 1.27$ \\
\hline$R: G$ ratio & $\sim 1: 5$ & $\sim 1: 6$ & $\sim 1: 2$ & $\sim 1: 7$ \\
\hline
\end{tabular}

The quantification of receptors and $G$ proteins via immunoblot was performed as described [23]. [ $\left.{ }^{3} \mathrm{H}\right] \mathrm{JNJ}-7753707$ saturation bindings were performed as described under Methods. ${ }^{35}$ S $]$ GTP $\gamma$ S saturation bindings were performed, using Sf9 cell membranes from the same batch of preparation. Reaction mixtures contained membranes (10 - $20 \mu \mathrm{g}$ of protein), 0.2 - 2 $\mathrm{nM}$ of $\left.{ }^{35} \mathrm{~S}\right] \mathrm{GTP} \gamma \mathrm{S}$, and unlabeled GTP $\gamma \mathrm{S}$ to give the desired final ligand concentrations for saturation $(0.2-50 \mathrm{nM})$. GDP or additional $\mathrm{H}_{3} \mathrm{R}$ ligands were not present in the reaction mixtures. Data were analyzed by nonlinear regression and were best fitted to hyperbolic onesite saturation isotherms. The maximal number of GTP $\gamma \mathrm{S}$ binding sites in membranes expressing $\mathrm{rH}_{3} \mathrm{R}$ plus $\mathrm{G} \mathrm{\alpha}_{\mathrm{i} 2}$ plus $\beta_{1} \gamma_{2}$ was corrected by the binding determined in $\mathrm{rH}_{3} \mathrm{R}$ plus $\beta_{1} \gamma_{2}$. By this way, the number of functionally intact and heterologously expressed $G$ protein $\alpha$ subunits was quantified. Data shown are the means \pm S. E. M. of 3 independent experiments performed in triplicate. Receptor-to-G protein ratios were calculated, using the $B_{\max }$ values determined for the different membrane preparations. 


\section{Table 2: Analysis of $\mathrm{rH}_{3} \mathrm{R} / \mathrm{G}$ protein coupling - GTPase activities in Sf9 membranes} expressing $\mathrm{rH}_{3} R$ and different $\mathrm{G}_{\alpha_{\mathrm{i} / \mathrm{o}}}$-proteins.

\begin{tabular}{|c|c|c|c|c|}
\hline \multirow{2}{*}{$\begin{array}{c}\text { GTPase activity } \\
\pm \text { S. E. M. }\end{array}$} & \multicolumn{4}{|c|}{$\mathrm{rH}_{3} \mathrm{R}+\beta_{1} \gamma_{2}$} \\
\hline & $+G \alpha_{i 1}$ & $+G \alpha_{i 2}$ & $+\mathrm{G} \alpha_{\mathrm{i} 3}$ & $+G \alpha_{01}$ \\
\hline $\begin{array}{c}\text { basal } \\
\left(\mathrm{pmol} \times \mathrm{mg}^{-1} \times \mathrm{min}^{-1}\right)\end{array}$ & $1.22 \pm 0.21$ & $1.75 \pm 0.22$ & $1.12 \pm 0.04$ & $4.29 \pm 0.12$ \\
\hline $\begin{array}{c}+ \text { ago } \\
\left(\mathrm{pmol} \times \mathrm{mg}^{-1} \times \mathrm{min}^{-1}\right)\end{array}$ & $2.01 \pm 0.26$ & $3.17 \pm 0.37$ & $2.13 \pm 0.14$ & $5.95 \pm 0.14$ \\
\hline $\begin{array}{c}\Delta \text { ago. } \\
\left(\mathrm{pmol} \times \mathrm{mg}^{-1} \times \mathrm{min}^{-1}\right)\end{array}$ & $0.79 \pm 0.07$ & $1.42 \pm 0.15$ & $1.01 \pm 0.10$ & $1.66 \pm 0.09$ \\
\hline $\begin{array}{c}\text { Agonist stimulation } \\
\text { (\% of basal) }\end{array}$ & $67.44 \pm 0.09$ & $81.78 \pm 2.32$ & $89.38 \pm 5.14$ & $38.78 \pm 2.38$ \\
\hline $\begin{array}{c}+ \text { inv. ago. } \\
\left(\mathrm{pmol} \times \mathrm{mg}^{-1} \times \mathrm{min}^{-1}\right)\end{array}$ & $0.71 \pm 0.10$ & $0.85 \pm 0.12$ & $0.59 \pm 0.03$ & $2.86 \pm 0.14$ \\
\hline $\begin{array}{c}\Delta \text { inv. ago. } \\
\left(\mathrm{pmol} \times \mathrm{mg}^{-1} \times \mathrm{min}^{-1}\right)\end{array}$ & $0.51 \pm 0.13$ & $0.90 \pm 0.10$ & $0.53 \pm 0.02$ & $1.43 \pm 0.13$ \\
\hline $\begin{array}{c}\text { Inverse agonist } \\
\text { inhibition } \\
\text { (\% of basal) }\end{array}$ & $40.32 \pm 5.93$ & $51.66 \pm 0.96$ & $47.4 \pm 0.82$ & $33.29 \pm 2.88$ \\
\hline
\end{tabular}

Steady-state GTPase experiments were performed as described in Methods. Reaction mixtures contained $0.1 \mu \mathrm{Ci}\left[\gamma_{-}{ }^{32} \mathrm{P}\right] \mathrm{GTP}$ and $100 \mathrm{nM}$ unlabeled GTP in the presence of solvent (basal), $10 \mu \mathrm{M} \mathrm{HA}$ (+ ago.) or $10 \mu \mathrm{M} \mathrm{THIO} \mathrm{(+} \mathrm{inv.} \mathrm{ago.).} \mathrm{Data} \mathrm{shown} \mathrm{are} \mathrm{the} \mathrm{means} \pm \mathrm{S}$. E. M. of three to four independent experiments for each membrane preparation performed in duplicates. The absolute agonist-stimulation ( $\Delta$ ago.) and inverse agonist-inhibition ( $\Delta$ inv. ago.) of GTP hydrolysis, as well as the relative agonist-stimulation and inverse agonistinhibition of GTP hydrolysis (\% of basal), were calculated. 


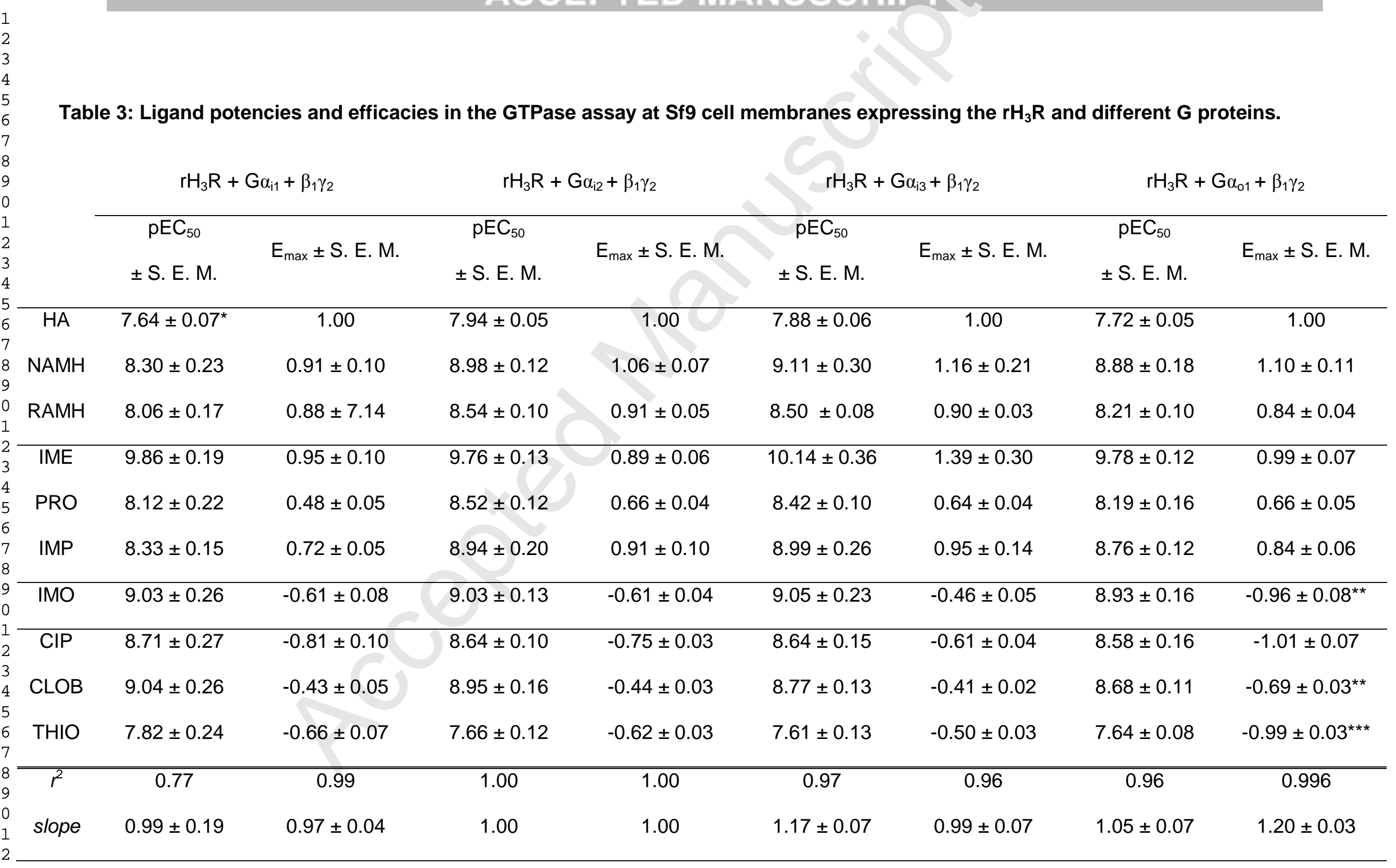


Steady-state GTPase activity in Sf9 membranes expressing $\mathrm{rH}_{3} \mathrm{R}$, different $\mathrm{G} \alpha_{\mathrm{i} / \mathrm{o}}$ subunits and $\beta_{1} \gamma_{2}$ was determined as described under Materials and Methods. Reaction mixtures contained ligands at concentrations from $0.1 \mathrm{nM}$ to $10 \mu \mathrm{M}$ as appropriate to generate saturated concentration/response curves. Data were analyzed by nonlinear regression and were best fit to sigmoid concentration/response curves. Typical basal GTPase activities ranged between 1.0 and $4.0 \mathrm{pmol}^{*} \mathrm{mg}^{-1}{ }^{*} \mathrm{~min}^{-1}$, and the maximal stimulatory effect of histamine (10 $\left.\mu \mathrm{M}\right)$ amounted to $\sim 40$ to $\sim 90 \%$ above basal. The efficacy $\left(E_{\max }\right)$ of histamine was determined by nonlinear regression and was set to 1.00 . The $E_{\max }$ values of other agonists and inverse agonists were referred to this value. Data shown are the means $\pm \mathrm{S}$. E. M. of three to four experiments performed in duplicates each. Statistical analysis was performed using one-way ANOVA, followed by Dunnet's multiple comparison test using the values determined at $\mathrm{hH}_{3} \mathrm{R}, \mathrm{G} \alpha_{\mathrm{i} 2}$ and $\beta_{1} \gamma_{2}$ as a reference. Significant differences to the membrane expressing $\mathrm{G} \alpha_{\mathrm{i} 2}$ are shown following comparison with other $\mathrm{G \alpha}_{\mathrm{i} / \mathrm{o}}$ subunits. (no symbol: not significant; ${ }^{*}, p<0.05 ;{ }^{* *}, p<0.01 ;{ }^{* \star *}, p<0.001$ ). Additionally, data shown were correlated and analyzed by linear regression. The potencies and efficacies of ligands at membranes co-expressing the $\mathrm{rH}_{3} \mathrm{R}, \mathrm{G} \alpha_{\mathrm{i} 1}, \mathrm{G} \alpha_{\mathrm{i} 3}$ or $\mathrm{G} \alpha_{01}$, and $\beta_{1} \gamma_{2}$ dimers, respectively, were correlated with values determined at the reference membrane expressing $\mathrm{Ga}_{\mathrm{i} 2}$. The correlation coefficients $\left(r^{2}\right)$ and the slopes are presented at the bottom of the table. 
Table 4: $\left[{ }^{3} \mathrm{H}\right] \mathrm{NAMH}$ competition bindings in $\mathrm{Sf9}$ membranes expressing $\mathrm{hH}_{3} \mathrm{R}$ or $\mathrm{rH}_{3} \mathrm{R}$ in combination with $\mathrm{G}_{\alpha_{\mathrm{i} 2}}$ and $\beta_{1} \gamma_{2}$.

\begin{tabular}{|c|c|c|}
\hline & \multicolumn{2}{|c|}{$\mathrm{p} K_{\mathrm{i}} \pm \mathrm{S} . \mathrm{E} . \mathrm{M}}$. \\
\hline & $\mathrm{hH}_{3} \mathrm{R}+\mathrm{G} \alpha_{\mathrm{i} 2}+\beta_{1} \gamma_{2}$ & $\mathrm{rH}_{3} \mathrm{R}+\mathrm{G} \alpha_{\mathrm{i} 2}+\beta_{1} \gamma_{2}$ \\
\hline HA & $8.20 \pm 0.04$ & $7.89 \pm 0.07$ \\
\hline $\mathrm{NAMH}$ & $9.22 \pm 0.03$ & $8.70 \pm 0.09$ \\
\hline RAMH & $8.91 \pm 0.07$ & $8.62 \pm 0.07$ \\
\hline IME & $9.20 \pm 0.05$ & $9.38 \pm 0.08$ \\
\hline PRO & $7.87 \pm 0.07$ & $8.08 \pm 0.10$ \\
\hline IMP & $8.84 \pm 0.06$ & $10.11 \pm 0.05$ \\
\hline $\mathrm{IMO}$ & $6.92 \pm 0.06$ & $8.47 \pm 0.09$ \\
\hline CIP & $7.03 \pm 0.12$ & $8.87 \pm 0.08$ \\
\hline CLOB & $9.34 \pm 0.06$ & $9.11 \pm 0.06$ \\
\hline THIO & $7.34 \pm 0.04$ & $7.94 \pm 0.04$ \\
\hline$r^{2}\left(\mathrm{p} K_{\mathrm{i}} / \mathrm{p} E C_{50}\right)$ & 0.83 & 0.50 \\
\hline slope $\left(\mathrm{p} K_{\mathrm{i}} / \mathrm{p} E C_{50}\right)$ & $0.94 \pm 0.15$ & $0.83 \pm 0.29$ \\
\hline
\end{tabular}

Experiments were performed as described under Methods. Reaction mixtures contained Sf9 membranes (10 - $50 \mu \mathrm{g}$ of protein), $1 \mathrm{nM}\left[{ }^{3} \mathrm{H}\right] \mathrm{NAMH}$, and unlabeled ligands at concentrations of $0.1 \mathrm{nM}$ to $10 \mu \mathrm{M}$ as appropriate to generate saturated competition curves. Data were analyzed by nonlinear regression and were best fit to one-site (monophasic) competition curves. Data shown are the means $\pm S$. E. M. of three to five independent experiments performed in duplicate at 3 different membrane preparations. Additionally, data shown were correlated and analyzed by linear regression. The affinities and potencies of ligands at membranes co-expressing the $\mathrm{hH}_{3} \mathrm{R}$ or $\mathrm{rH}_{3} \mathrm{R}$ plus $\mathrm{G} \alpha_{\mathrm{i} 2}$ plus $\beta_{1} \gamma_{2}$ dimers, respectively, were correlated. The correlation coefficients $\left(r^{2}\right)$ and the slopes of all tested ligands are presented at the bottom of the table. 
Figure 1

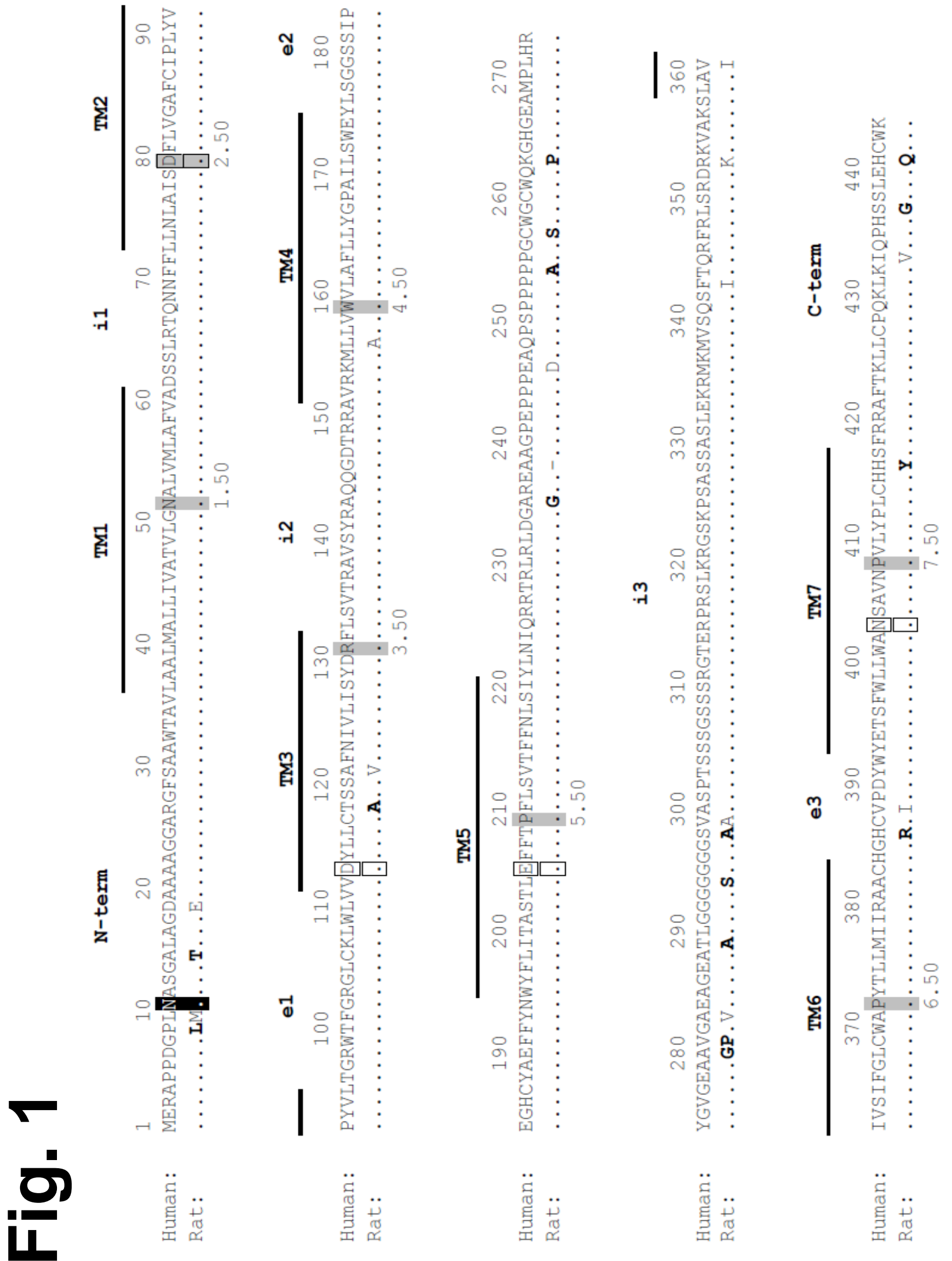




\section{Fig. 2}<smiles>NCCc1c[nH]cn1</smiles>

histamine (HA), 1<smiles>CNCCc1c[nH]cn1</smiles>
$\mathrm{N}^{\alpha}$-methylhistamine (NAMH), 2<smiles>C[C@H](N)Cc1c[nH]cn1</smiles>

(R)-a-methylhistamine (RAMH), 3<smiles>N=C(N)SCCc1c[nH]cn1</smiles>
imetit (IME), 4<smiles>c1ccc(COCCCc2c[nH]cn2)cc1</smiles>
proxifan (PRO), 5<smiles>NCCCCCc1c[nH]cn1</smiles>

impentamine (IMP), 6<smiles>C/C(=N\O)c1ccc(OCCCc2c[nH]cn2)cc1</smiles>
imoproxifan (IMO), 7<smiles>O=C(c1ccc(OCCCc2c[nH]cn2)cc1)C1CC1</smiles>

ciproxifan (CIP), 8<smiles>N=C(NCc1ccc(Cl)cc1)SCCCc1c[nH]cn1</smiles><smiles>S=C(NC1CCCCC1)N1CCC(c2c[nH]cn2)CC1</smiles>

thioperamide (THIO), 10 
A anti-hH $\mathrm{H}_{3} \mathrm{R}$

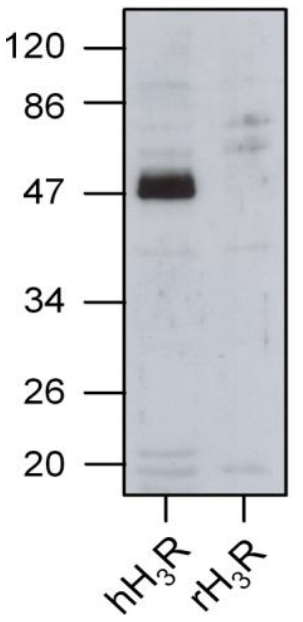

\section{D1 anti-FLAG}

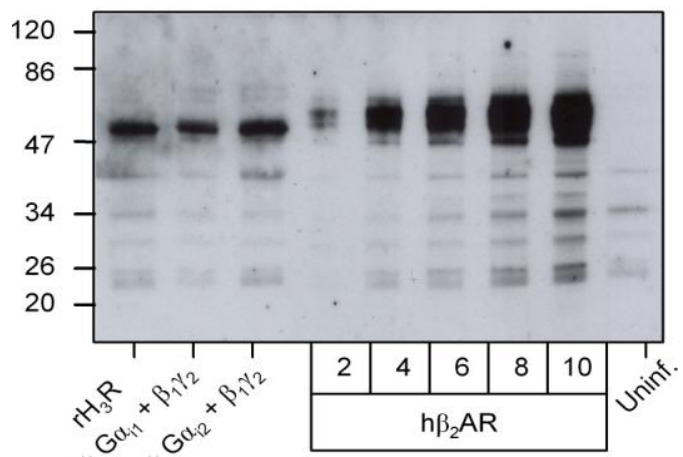

E anti-6His

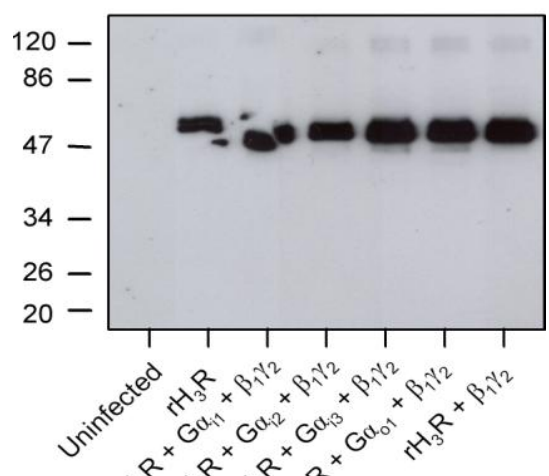

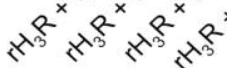

H anti-G $\alpha_{i 1 / 2}$

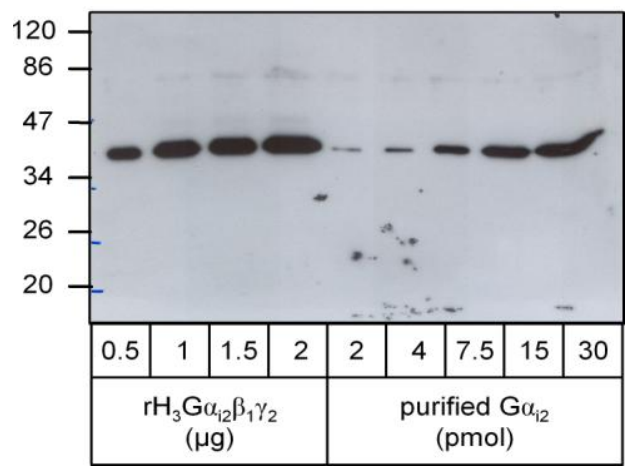

B anti-r $\mathrm{H}_{3} \mathrm{R}$

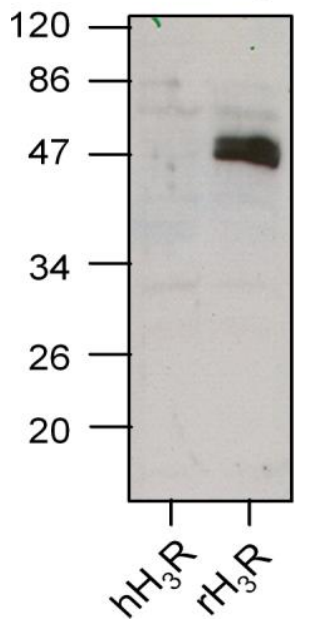

D2 anti-FLAG
C anti- $\mathrm{H}_{3} \mathrm{R}(\mathrm{i} 3)$

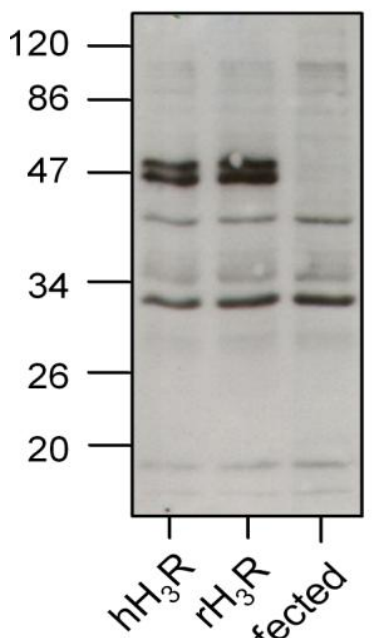

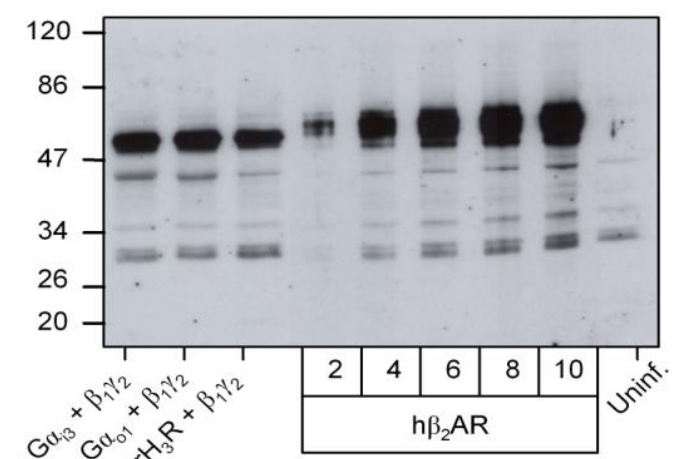

F anti-G $\alpha_{\mathrm{i}-\mathrm{com}}$.

G anti-G $\beta_{\text {i-com. }}$.
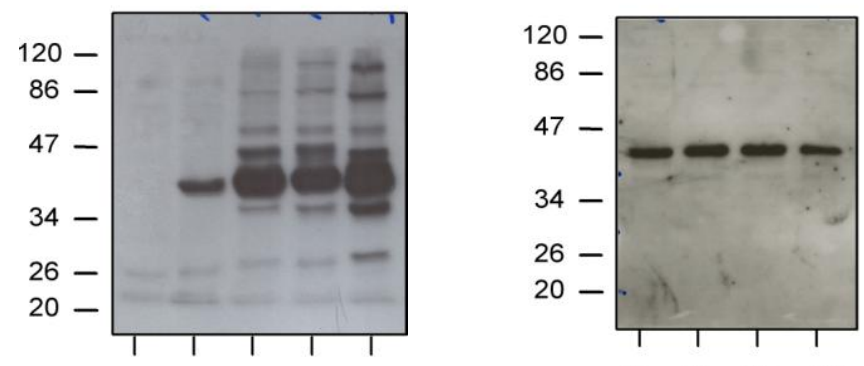

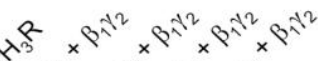

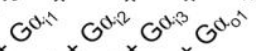

$x^{R^{x}} x^{R^{x}} x^{r^{x}} x^{R^{x}}$

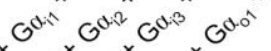

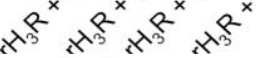
anti-G $\alpha_{0}$

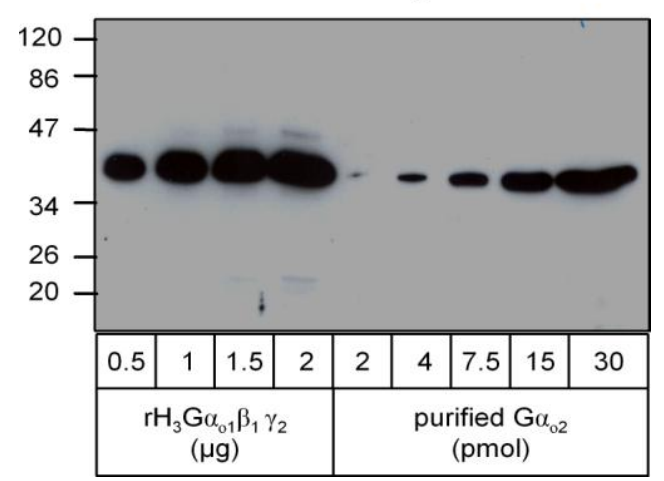


Figure 4

Fig. 4
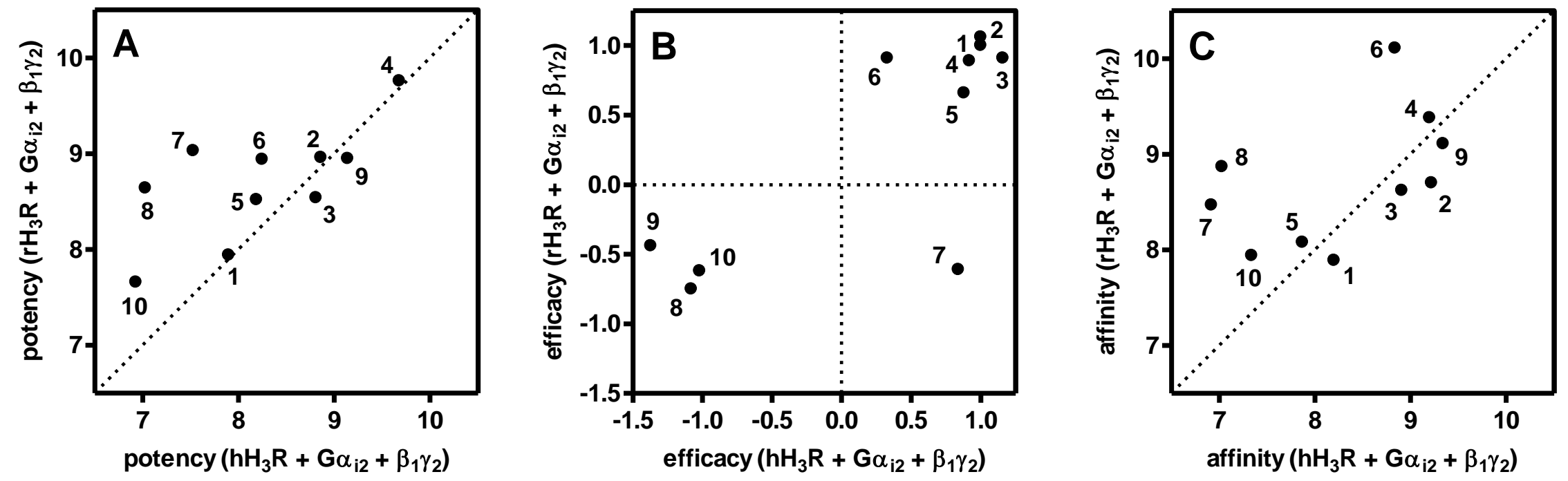


\section{Fig. 5}
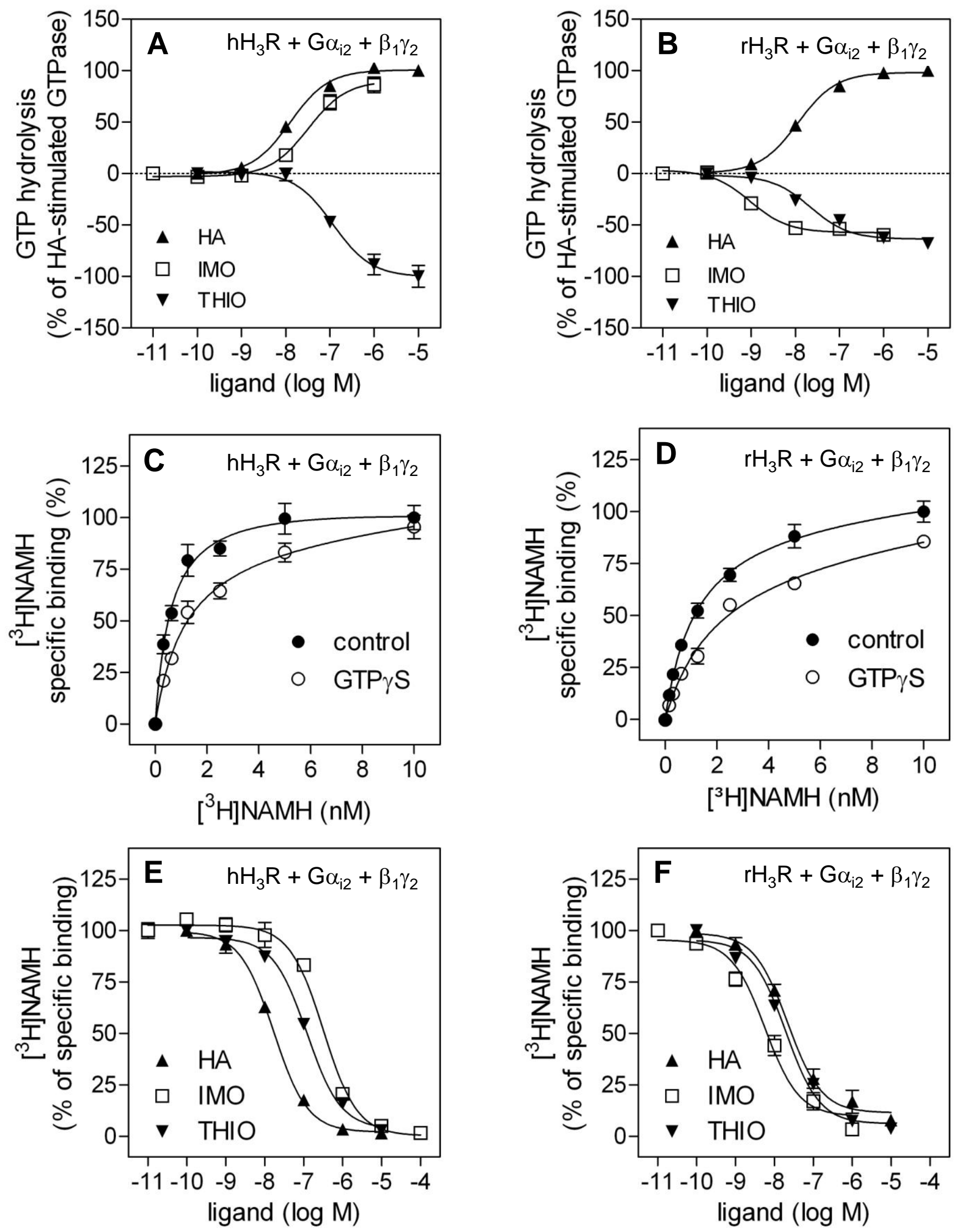


\section{Fig. 6}
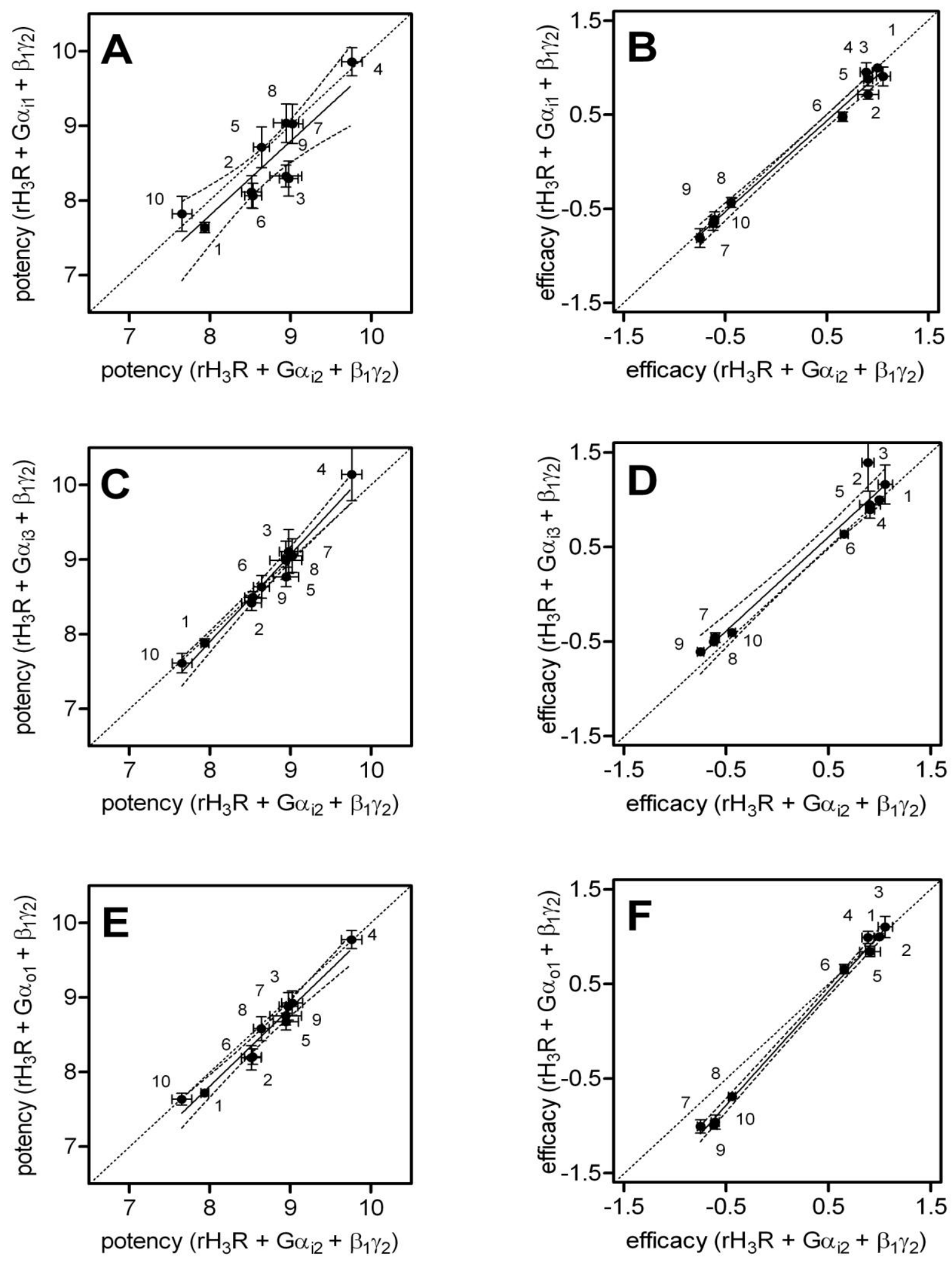
Figure 7
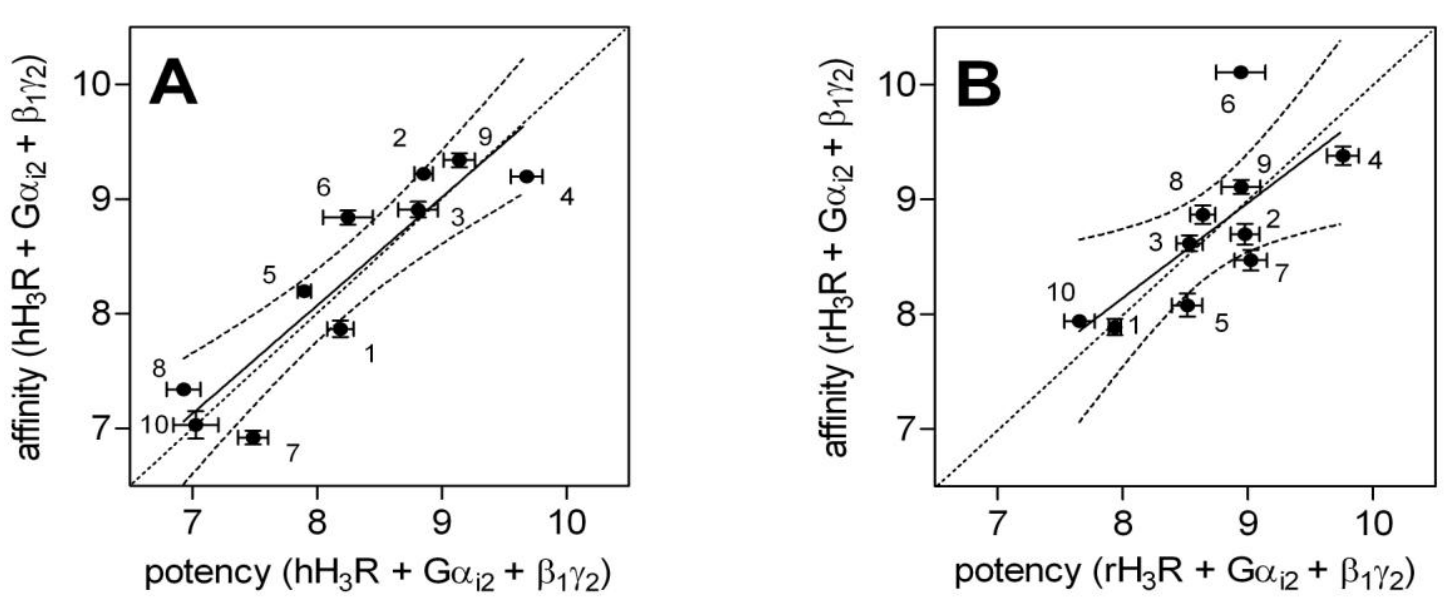

potency ${ }_{\left(\mathrm{hH}_{3} \mathrm{R}+\mathrm{G \alpha}_{\mathrm{i}}+\beta_{1} \gamma_{2}\right)}$ 
Fig. 8
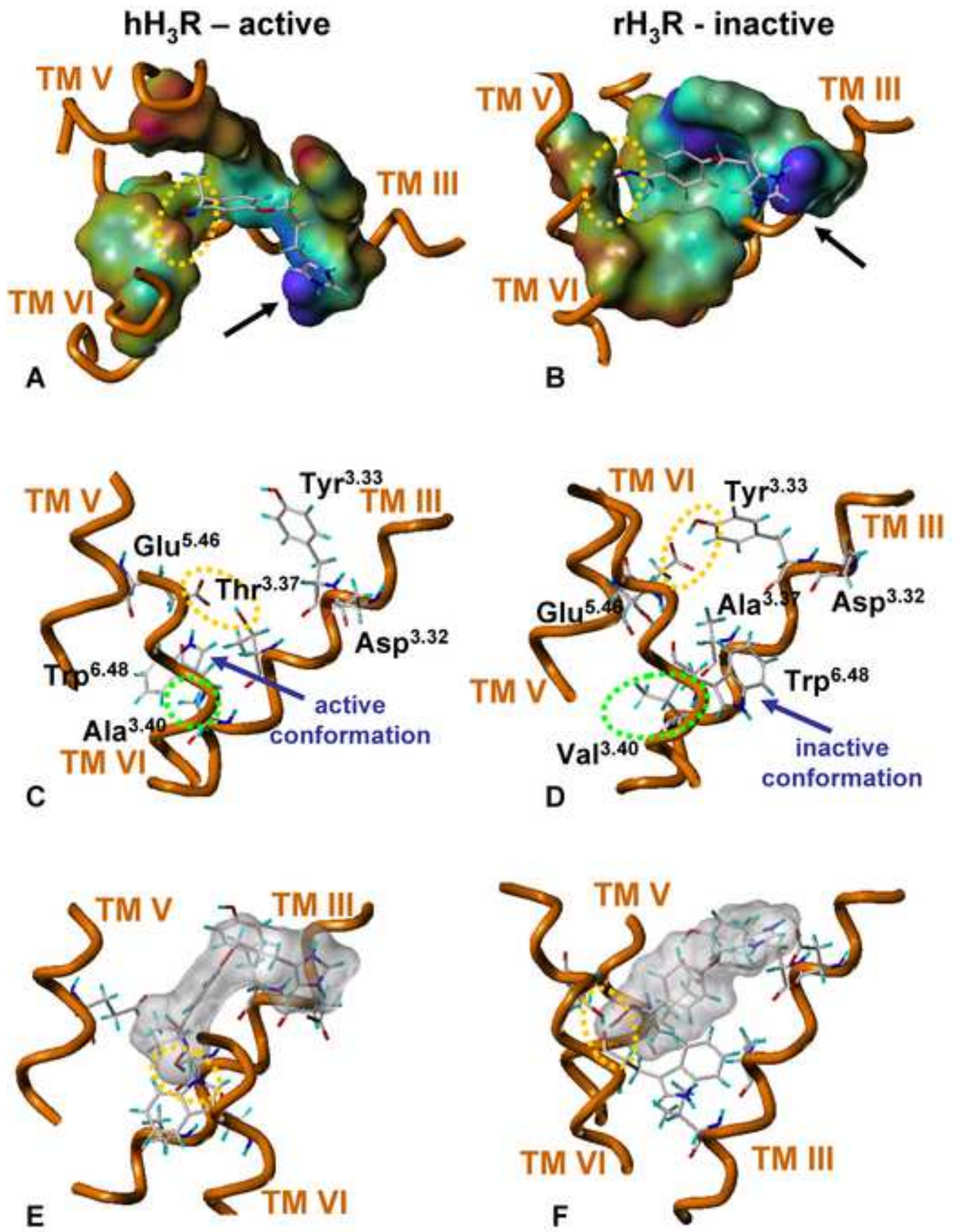


\section{Graphical Abstract}
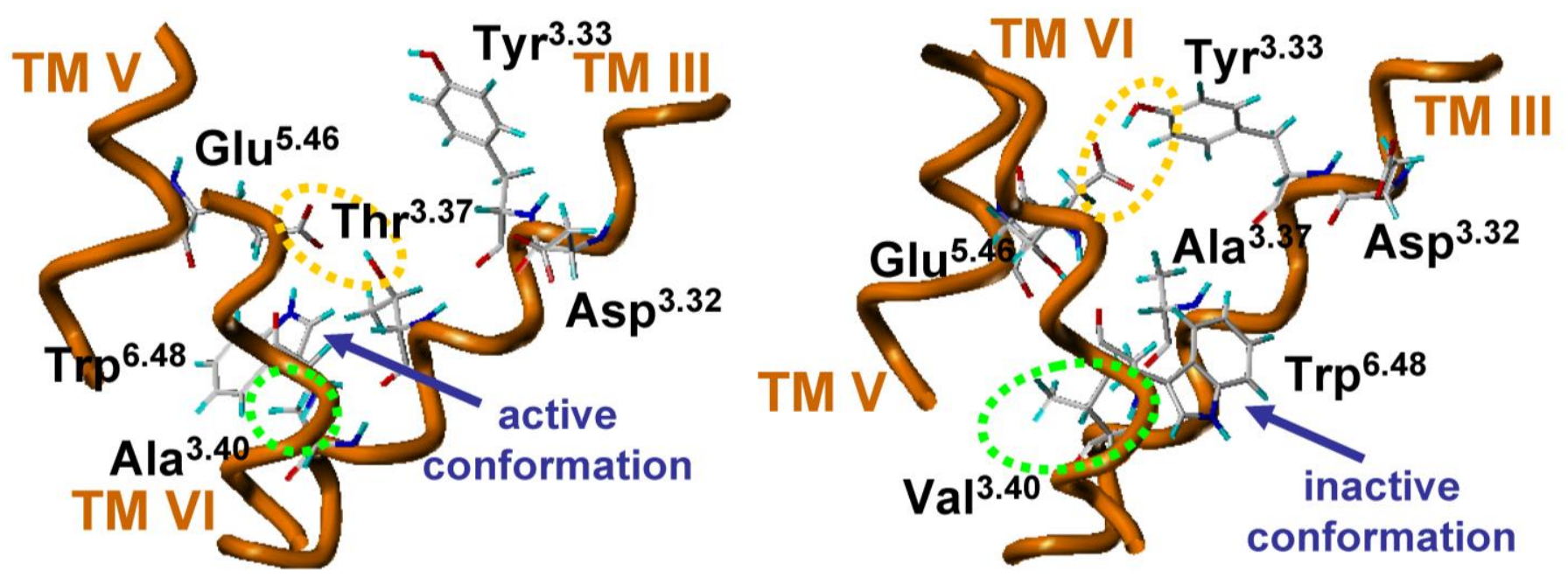

This paper documents substantial pharmacological differences between human and rat histamine $\mathrm{H}_{3}$-receptor. Most strikingly, in human $\mathrm{H}_{3}$-receptor, imoproxifan stabilizes an active conformation. In rat $\mathrm{H}_{3}$-receptor, imoproxifan stabilizes an inactive conformation. 